\title{
Marine-Derived Compounds for the Potential Treatment of Glucocorticoid Resistance in Severe Asthma
}

\author{
Cristina Mihaela Ghiciuc ${ }^{1, *,+} \mathbb{D}$, Andrei Gheorghe Vicovan ${ }^{1, *,+}$, Celina Silvia Stafie ${ }^{2,+}$ (D), \\ Sabina Antonela Antoniu $3,+(\mathbb{D}$ and Paraschiva Postolache $4,+$
}

1 Department of Morpho-Functional Sciences II—Pharmacology and Clinical Pharmacology, Faculty of Medicine, Grigore T. Popa University of Medicine and Pharmacy of Iași, 16 Universitatii Street, 700115 Iasi, Romania

2 Department of Preventive Medicine and Interdisciplinarity-Family Medicine Discipline, Faculty of Medicine, Grigore T. Popa University of Medicine and Pharmacy of Iasi, 16 Universitatii Street, 700115 Iasi, Romania; celina.stafie@umfiasi.ro

3 Department of Medicine II-Palliative Care Nursing, Grigore T. Popa University of Medicine and Pharmacy of Iasi, 16 Universitatii Street, 700115 Iasi, Romania; sabina.antoniu@umfiasi.ro

4 Department of Medicine I-Pulmonary Rehabilitation Clinic, Grigore T. Popa University of Medicine and Pharmacy of Iasi, 16 Universitatii Street, 700115 Iasi, Romania; paraschiva.postolache@umfiasi.ro

* Correspondence: cristina.ghiciuc@umfiasi.ro (C.M.G.); andrei.vicovan@email.umfiasi.ro (A.G.V.)

+ These authors contributed equally to this work.

Citation: Ghiciuc, C.M.;

Vicovan, A.G.; Stafie, C.S.;

Antoniu, S.A.; Postolache, P.

Marine-Derived Compounds for the Potential Treatment of Glucocorticoid Resistance in Severe Asthma. Mar. Drugs 2021, 19, 586. https://doi.org/ $10.3390 / \operatorname{md} 19110586$

Academic Editor: Bill J. Baker

Received: 30 September 2021

Accepted: 15 October 2021

Published: 20 October 2021

Publisher's Note: MDPI stays neutral with regard to jurisdictional claims in published maps and institutional affiliations.

Copyright: (c) 2021 by the authors. Licensee MDPI, Basel, Switzerland. This article is an open access article distributed under the terms and conditions of the Creative Commons Attribution (CC BY) license (https:// creativecommons.org/licenses/by/ $4.0 /)$

\begin{abstract}
One of the challenges to the management of severe asthma is the poor therapeutic response to treatment with glucocorticosteroids. Compounds derived from marine sources have received increasing interest in recent years due to their prominent biologically active properties for biomedical applications, as well as their sustainability and safety for drug development. Based on the pathobiological features associated with glucocorticoid resistance in severe asthma, many studies have already described many glucocorticoid resistance mechanisms as potential therapeutic targets. On the other hand, in the last decade, many studies described the potentially anti-inflammatory effects of marine-derived biologically active compounds. Analyzing the underlying anti-inflammatory mechanisms of action for these marine-derived biologically active compounds, we observed some of the targeted pathogenic molecular mechanisms similar to those described in glucocorticoid (GC) resistant asthma. This article gathers the marine-derived compounds targeting pathogenic molecular mechanism involved in GC resistant asthma and provides a basis for the development of effective marine-derived drugs.
\end{abstract}

Keywords: marine-derived compounds; glucocorticoid-resistant; severe asthma; drug development; biomedical applications

\section{Introduction}

Asthma is a chronic inflammatory disease of the lower airways characterized by airway hyperresponsiveness and remodeling, leading to wheeze, cough, chest tightness, and difficulty in breathing. The prevalence of asthma is still increasing, while the potential risk factors for asthma seems to make equal contributions [1]. Although among the population of adults with asthma only 3\% to $10 \%$ are classified as suffering from severe asthma [2,3], the costs of healthcare per patient are higher than those for stroke, type 2 diabetes, or chronic obstructive pulmonary disease (COPD) [4]. According to the current guidelines [5], difficult-to-control asthma is asthma that is uncontrolled despite treatment with high-dose inhaled glucocorticoids (ICS) combined with long-acting $\beta_{2}$-agonists or other controllers, or that requires such treatment to maintain good symptom control and reduce exacerbation; severe asthma is considered a subset of difficult-to-control asthma that is uncontrolled despite adherence to maximal optimized Step 4 or Step 5 therapy and treatment of contributory factors, or that worsens when high-dose treatment is reduced. 
Glucocorticoid resistance in the main challenge of severe asthma. A common feature of patients with severe asthma is their poor response to high doses of ICS and then systemic glucocorticoids (GCs). This inadequate response is called steroid-unresponsive or GC resistance. These patients, however, may respond well to $\beta 2$-adrenergic agonist-mediated vasodilation; but if after 2 weeks of appropriate-dose steroid treatment the improvements in forced expiratory volume in $1 \mathrm{~s}$ (FEV1) are $<15 \%$, then the asthma is defined as GC resistant [6-8].

Compounds derived from marine sources have received increasing interest in recent years due to their prominent biologically active properties for biomedical applications, and to their being a new and safe source for drug development [9-13]. New compounds were recently reviewed and proposed as potential treatments for different diseases, such as cancer [14], cardiovascular diseases [15], rheumatoid arthritis [16], neurological diseases [17], and others.

Many marine-derived biologically active compounds target pathogenic molecular mechanisms common to those described in GC-resistant asthma; therefore, we sought in this review to gather the marine-derived compounds targeting the pathogenic molecular mechanism involved in GC resistant asthma and to provide a basis for the development of effective marine-derived drugs.

\section{Pathobiological Features Associated with Glucocorticoid Resistance}

In practice, the diagnosis of GC resistance in asthma is based on the clinical history and evaluation of respiratory function after sufficient steroid treatments. Often, patients receive increasing doses of steroids for extended periods, until it is recognized that this is ineffective for treating their severity of asthma. The toxic side effects of long-term high-dose steroids are well known for increasing susceptibility to infections, cardiovascular disease, hyperglycemia, and osteoporosis. Although there are currently no clinically accepted biomarkers or phenotypes for resistance, some studies identified asthma phenotypes associated with GC resistance $[5,18,19]$, as depicted in Table 1.

Table 1. Degree of Glucocorticoid Resistance and Corresponding Asthma Phenotypes.

\begin{tabular}{|c|c|c|}
\hline $\begin{array}{c}\text { Degree of Glucocorticoid } \\
\text { Resistance }\end{array}$ & Asthma Phenotypes & Pathobiologic Features \\
\hline \multirow{3}{*}{$\begin{array}{l}\text { Severe corticosteroid } \\
\text { resistance }\end{array}$} & Obesity-related asthma & $\begin{array}{l}\text { Absence of Th2 specific response } \\
\text { Increased oxidative stress }\end{array}$ \\
\hline & Neutrophilic asthma & $\begin{array}{l}\text { Increased Th-17 response } \\
\text { (increased IL-8, neutrophilia) }\end{array}$ \\
\hline & $\begin{array}{l}\text { Late-onset eosinophilic } \\
\text { asthma }\end{array}$ & $\begin{array}{l}\text { Increased IL-5 } \\
\text { Eosinophilia }\end{array}$ \\
\hline \multirow[b]{2}{*}{$\begin{array}{l}\text { Moderate corticosteroid } \\
\text { resistance }\end{array}$} & Early-onset allergic asthma & $\begin{array}{l}\text { Increased Th2 specific response } \\
\text { Presence of antigen-specific IgE }\end{array}$ \\
\hline & Exercise-induced asthma & $\begin{array}{c}\text { Increased Th2 specific response } \\
\text { Increased mast } \\
\text { cells degranulation } \\
\text { Increased CysLTs }\end{array}$ \\
\hline
\end{tabular}

Th, T helper lymphocyte; Ig, Immunoglobuline; IL, interleukin; CysLTs, cystenyl leukotrienes.

\section{Mechanisms of Glucocorticoid Resistance as Potential Therapeutic Targets}

\subsection{Mechanisms of Action of Glucocorticoids}

Although the topic has been extensively reviewed by Keenan et al. [20] and many others [7,21-23], before delving into the altered cellular and molecular basis of signaling that leads to GCs resistance, it is important to review the heterogenous mechanisms of action by which GCs exert their downstream effect.

GCs have been extensively used in many diseases for a long time, but their molecular mechanisms of action are still not completely understood. GCs bind on the intracellular 
glucocorticoid receptors (GRs) of the target cell. There are two major variants of GRs with different C-terminal domains: GR- $\alpha$, and GR- $\beta$. GR- $\alpha$ isoform-bind to GCs and affect GR signaling pathways through various post-translational modifications, such as phosphorylation, acetylation, and other modifications [24], while GR- $\beta$ is unable to bind to GCs and cannot affect GC-induced modification. GR- $\beta$ probably regulates GC activity, antagonizes GR- $\alpha$ isoform, and regulates GR- $\alpha / \beta$ heterodimers $[25,26]$.

Genomic mechanisms are mediated by binding to GRs in the cytoplasm and further translocation of the GC/GR complex into the nucleus, while non-genomic mechanisms are mediated through specific interaction with GRs, or nonspecific interactions with the cell membrane [27]. Intracytoplasmic GRs present in inactive forms, in a protein complex, and attached to a chaperone protein. The dissociation of GR and the dissociation of chaperone protein upon activation allow the translocation of GR into the nucleus [28]. Inside the nucleus, the GC/GR complex regulates up to $20 \%$ of genes expressed by immune cells by trans-repressing inflammatory genes and stimulating the transcription of anti-inflammatory genes, leading to the reduced activation, recruitment, and survival of inflammatory and epithelial cells [29-31]; it also regulates mRNA stability [32] and the immunomodulatory function of smooth muscle cells and airway remodeling in asthma [33].

High concentrations of GCs exert non-genomic actions; inhibit the degranulation of mast cells through the stabilization of the plasma membrane or through a reduction in $[\mathrm{Ca} 2+]$ elevation [34]; and promote anti-inflammatory effects through negative interference with MAPK signaling pathways [35].

\subsection{Glucocorticoids Resistance: Cellular and Molecular Basis}

Decreased GC responsiveness can be inherited or acquired. In the case of inherited decreased GC responsiveness, GC insensitivity most probably is not caused by a singular genetic mutation and involves a range of genetic variations. Some of the involved genes have already been determined [36-38] and are not the aim of our study.

The research into specific studies dedicated to GC resistance revealed the following responsible mechanisms:

- Deficient binding between the GC and the GR or between the GR complex and DNA may be a cause [39].

- Increased antagonism is determined either by increased GR- $\beta$ expression [40] or by diminished GR- $\alpha$ expression [41]. This can be explained by the IL-2/IL-4-induced suppression of GR- $\alpha$ (and not GR- $\beta$ ) expression in peripheral blood mononuclear cells (PBMCs) [42]. Additionally, IL-2 and IL-4 can synergistically reduce (via the p38MAPK pathway) nuclear translocation and binding affinity in T-cells (reversible by a p38 inhibitor) [43]. Furthermore, IL-17 and IL-23 cytokines were reported to significantly upregulate GR- $\beta$ [42].

- Inflammation or oxidative stress has the potential to negatively affect GC signaling [22].

- The expression of various anti-inflammatory genes induced by GCs can be reduced through GR phosphorylation by, for example, p38 mitogen-activated protein kinase (MAPK) and by the reduced activity of histone deacetylase 2 (HDAC2) [43,44].

- The upregulation of certain cytokines, such as IL-2, IL-4, and IL-13, was detected in the lungs of patients with GC unresponsiveness [45-47]; in vitro, the overexpression of these cytokines was associated with the phosphorylation of GR and a decrease in nuclear translocation in inflammatory cells through the activation of p38 mitogenactivated protein kinase [48]. p38MAPK activity was demonstrated to be higher in alveolar macrophages from patients with impaired response to GCs compared to 'responders'. Furthermore, the expression of MKP-1 (DUSP1 gene), an endogenous inhibitor of the MAPK pathway, was significantly diminished in alveolar macrophages after GCS exposure, leading to an increase in p38MAPK activity [49]. Furthermore, p38MAPK inhibitors, such as AZD7624 or SB203580, have recently been investigated in corticosteroid-resistant asthmatic populations [50,51]. 
- Increased HDAC activity using theophylline, PI3K, and p38 MAPK inhibitors demonstrated beneficial effects [52-54], especially in glucocorticoid-resistant asthmatic smokers, where increased antagonism of the GR- $\alpha$ resulted from a reduced ratio of GR- $\alpha$ to GR- $\beta$ isoforms [55]. Moreover, reduced total HDAC activity in PBMCs isolated from prednisone-dependent asthmatics compared to ICS-maintained moderate asthmatics and healthy volunteers was reported [56].

- GC resistance has been associated with Haemophilus influenzae, Chlamydia pneumoniae, Influenza A virus (IAV), rhinovirus, and Respiratory syncytial virus (RSV) infections [57-61]. The molecular mechanism proposed for glucocorticoid insensitivity in rhinovirusinfected primary human bronchial epithelial cells is the activation of NF- $\mathrm{kB}$ and c-Jun $\mathrm{N}$-terminal kinase, which leads to a decrease in GR- $\alpha$ nuclear translocation [62]. The influence of NF- $\mathrm{KB}$ activity on GC resistance has also been confirmed by research on the blockade of this pathway $[63,64]$.

- Using mouse models of steroid-resistant asthma driven by bacterial (Chlamydia and Haemophilus influenzae) and viral (influenza and RSV) respiratory tract infections, Kim et al. demonstrated that steroid insensitivity can be induced through PI3K-mediated phosphorylation and the nuclear translocation of pAKT [65].

- $\quad$ By upregulating miR-9 expression in pulmonary macrophages, IFN- $\gamma$ can increase GR phosphorylation and, consequently, inhibit GR nuclear translocation in experimental models of steroid-resistant airway hyperresponsiveness [66].

- In a study of human fetal airway smooth muscle cells, TNF- $\alpha$ and IFN- $\gamma$ cytokines were shown to sustain GC resistance by promoting the Nuclear factor- $\mathrm{kB}$ (NF- $\mathrm{kB}$ ) pathway and Stat1 phosphorylation [67]. TNF- $\alpha$ also demonstrated the potential to activate the c-Jun N-terminal kinase (JNK), which directly phosphorylated GR- $\alpha$ at Ser226 and inhibited GRE-binding [68].

- The nitrosylation of the glucocorticoid receptor at the HSP90 (chaperone) binding site can be caused by high levels of nitric oxide generated in situ as a result of eosinophilic inflammation. This can decrease its affinity with chaperone proteins that protect it from cytoplasmic degradation. The binding affinity to GCs (ligand) in structural cells, such as fibroblasts, can also be reduced by nitrosylation [69]. In conclusion, asthmatics with persistent airway eosinophilia with increased localized nitric oxide production and possibly increased remodeling may develop GC resistance through the repeated nitrosylation of GR.

- Increased NLR Family Pyrin Domain Containing 3 (NLRP3) inflammasome/IL-1 $\beta$ activation contributed to glucocorticoid resistance in murine models of steroid-resistant allergic airway disease [70].

- The Th2 cytokines IL-13 and IL-5 each possess the ability to induce diminished GRbinding affinity. The effect of hydrocortisone in suppressing LPS-induced IL-6 production by monocytes was demonstrated to be significantly hindered when the cells were primed by IL-13 [71]. Additionally, IL-5-primed eosinophils were unresponsive to GS-induced apoptosis (via synergistic upregulation of nuclear-factor IL-3 due to a cross-talk between GCS-induced trans-activation signaling and IL-5 antiapoptotic pathway) [72].

- The adoptive transfer of Th17 cells in mice resulted in the development of steroid insensitivity, and Th17 cells and IL-17A levels are frequently associated with CG resistance in asthmatic patients [73-75]. Accordingly, the expression of GR- $\beta$ has been reported to increase Th17 responses [76]. In the obesity phenotype of asthma, the associated steroid resistance may be induced by IL-17 produced by the pulmonary type 3 innate lymphoid cells [77]. The role of IL-7 in GC resistance has been confirmed by the augmentation of dexamethasone anti-inflammatory action in diesel exhaust particle-induced neutrophilic steroid insensitivity secondary to anti-IL-17 therapy [78].

- Bhavsar et al. showed that dexamethasone could not suppress the lipopolysaccharide (LPS)-induced release of pro-inflammatory cytokines [49]. This finding was supported by Li et al., who simulated an airway infection in a mouse model of steroid-resistant 
asthma through the concomitant administration of LPS + IFN $\gamma$; consequently, PP2A activity (that induced JNK) was attenuated and led to the phosphorylation of GR- $\alpha$ at Ser226, thereby hindering glucocorticoid receptor nuclear translocation in pulmonary macrophages [66].

- $\quad$ LPS promoted a shift from Th2-derived airway eosinophilic inflammation to Th17-drived neutrophilic inflammation in an ovalbumin-sensitized murine asthma model [79].

- Dysregulated IL-10 production is associated with GC insensitivity. This is probably due to impaired IL-10 production, according to Hawrylowicz et al., who compared in vitro stimulated $\mathrm{T}$ lymphocytes from corticosteroid-resistant asthmatic with dexamethasone to T lymphocytes from steroid-sensitive asthmatics [80].

- The induction of Th2/Th17 responses in fungus-exposed patients has the potential to develop GC resistance [65]. More precisely, in neonatal mice, Aspergillus alternata exposure induced IL-33 dependent GC resistant asthma, mediated by ILC2 and Th2 cells [81]. The suggested mechanism underlying glucocorticoid insensitivity is the activation of p38-MAPK in CD4 + T cells and induction of phosphorylation of GR by IL-33 [82].

GCs also produce pro-inflammatory effects under stress conditions [83]. Table 2 depicts the potential targeted molecular and immunopathogenic mechanisms in glucocorticoidresistant severe asthma.

Table 2. Potential targeted mechanisms in glucocorticoid-resistant severe asthma.

\begin{tabular}{|c|c|c|}
\hline Molecular Targets & Pharmacological Effect & References \\
\hline Decrease in activity of MAPK & $\begin{array}{l}\text { Decrease in GR phosphorylation } \\
\text { Increased ratio of GR- } \alpha \text { to GR- } \beta \text { isoforms }\end{array}$ & {$[43,44,48-55]$} \\
\hline Increase of activity of HDAC & $\begin{array}{l}\text { Decrease in GR phosphorylation } \\
\text { Increased ratio of GR- } \alpha \text { to GR- } \beta \text { isoforms }\end{array}$ & {$[43,44,52-54,56]$} \\
\hline Decrease in activation of JNK & $\begin{array}{c}\text { Decrease in GR phosphorylation } \\
\text { Increase in GR- } \alpha \text { nuclear translocation }\end{array}$ & $\begin{array}{l}{[68]} \\
{[62]}\end{array}$ \\
\hline Nitric oxide decrease & Decrease in nitrosylation of GR at HSP90 (chaperone binding site) & {$[69,84]$} \\
\hline Decrease inactivation of NF- $k B$ & Increase in GR- $\alpha$ nuclear translocation & {$[62-64,67]$} \\
\hline Decrease in oxidative stress & Multiple & [22] \\
\hline \multicolumn{3}{|l|}{ Downregulation of Th2 } \\
\hline IL-4 & $\begin{array}{c}\text { Increase in GR- } \alpha \text { expression and nuclear translocation } \\
\text { Increase in GR binding affinity in T-cells } \\
\text { Decrease in GR phosphorylation }\end{array}$ & {$[40-43,45-48]$} \\
\hline IL-5 & Increased GR binding affinity & {$[71,72]$} \\
\hline IL-13 & $\begin{array}{l}\text { Decrease in GR phosphorylation } \\
\text { Increased GR binding affinity }\end{array}$ & $\begin{array}{c}{[45-48]} \\
{[71]}\end{array}$ \\
\hline \multicolumn{3}{|l|}{ Downregulation of non-Th2 } \\
\hline IL-17 & Decrease in GR- $\beta$ expression & {$[42,76,77]$} \\
\hline IL-23 & Decrease in GR- $\beta$ expression & {$[42]$} \\
\hline IFN- $\gamma$ & $\begin{array}{c}\text { Decreased GR phosphorylation and stimulation of GR } \\
\text { nuclear translocation } \\
\text { Increase in GR- } \alpha \text { nuclear translocation (through downregulation } \\
\text { of NF- } \mathrm{kB} \text { ) }\end{array}$ & $\begin{array}{l}{[66]} \\
{[67]}\end{array}$ \\
\hline TNF- $\alpha$ & $\begin{array}{l}\text { Increase in GR- } \alpha \text { nuclear translocation (through downregulation } \\
\text { of NF- } \mathrm{k} \text { ) } \\
\text { Decrease in GR- } \alpha \text { phosphorylation at Ser226 and the inhibition of } \\
\text { GRE-binding (through downregulation of JNK) }\end{array}$ & $\begin{array}{l}{[67]} \\
{[68]}\end{array}$ \\
\hline
\end{tabular}


Table 2. Cont.

\begin{tabular}{ccc}
\hline Molecular Targets & Pharmacological Effect & References \\
\hline IL-33 & Decreased GR phosphorylation & Unknown \\
\hline IL-1 $\beta$ & [81,82] \\
\hline $\begin{array}{c}\text { Inhibition of inflammatory response shift: } \\
\text { Th2 to Th17 }{ }^{+}\end{array}$ & $\begin{array}{c}\text { Decreased GR phosphorylation and stimulate GR } \\
\text { nuclear translocation }\end{array}$ \\
& $\begin{array}{c}\text { Incease in GR- } \alpha \text { nuclear translocation (through downregulation } \\
\text { of NF- } k \text { B) }\end{array}$ \\
& $\begin{array}{c}\text { Decrease in GR- } \alpha \text { phosphorylation at Ser226 and the inhibition of } \\
\text { GRE-binding (through downregulation of JNK) }\end{array}$ \\
\hline
\end{tabular}

MAPK, Mitogen-activated protein kinase; GR, glucocorticoid receptor; HDAC, histone deacetylase; JNK, c-Jun N-terminal kinase; $\mathrm{HSP} 90$, heat shock protein; NF- $\mathrm{kB}$, Nuclear factor- $\mathrm{kB} ;{ }^{\dagger}$, inhibition of inflammatory response shift from Th2-derived airway eosinophilic inflammation to Th17-drived neutrophilic inflammation (through inhibition of LPS-induced release of pro-inflammatory cytokines).

\section{Potentially Therapeutic Effect of Marine-Derived Biologically Active Compounds in Severe Asthma}

Experimental studies with marine compounds demonstrating their effectiveness in in vitro or in vivo models of bronchial asthma are scarce [84-88]. On the other hand, recent studies revealed the significant potential of marine compounds to interfere with molecular mechanisms similar to those involved in GC-resistant asthma. Therefore, a standardized inclusion-exclusion criterion was implemented, aiming to justify the current review. The literature search queries were performed until September, 2021. We included and analyzed all the original articles from PubMed and Scopus databases, with marine compounds that potentially target these molecular mechanisms; we excluded reviews and generalized or irrelevant studies (results illustrated in Table 3).

Some of these compounds from different marine sources are well characterized and have well-defined structures (Table 4), while others are extracts with complex compositions.

\subsection{Cellular Signal/Corticoresistance}

Fucosterol, a phytosterol from the marine brown algae Padina boryana, demonstrated anti-inflammatory effects through its dose-dependent downregulation of pro-inflammatory cytokines (IL-1 $\beta$, IL-6 and TNF- $\alpha$ ) and of the Nrf2/HO-1 pathway [89].

Mojabanchromanol (MC), a chromanol isolated from the brown algae Sargassum horneri, demonstrated anti-oxidant effects through the attenuation of particulate matterinduced oxidative stress, the reduction of the ROS-mediated phosphorylation of MAPK extracellular signal-regulated kinase 1/2 (Erk1/2) and of c-JNK, and the inhibition of the secretion of pro-inflammatory cytokines (IL-6, IL-1 $\beta$ and IL-33). The authors proposed that mojabanchromanol be developed as a therapeutic agent against particulate matter-induced airway inflammatory responses [84].

Sargachromenol, isolated from Sargassum horneri, demonstrated anti-inflammatory effects in lipopolysaccharide (LPS)-stimulated RAW 264.7 macrophages, by reducing the nitric oxide (NO); and in intracellular reactive oxygen species (ROS), by decreasing the mRNA expression levels of inflammatory cytokines (IL-1 $\beta$, IL-6, and TNF- $\alpha$ ) and by inhibiting the activation of NFKB and MAPK signaling [90]. 
Table 3. Potential targeted mechanisms in glucocorticoid-resistant severe asthma.

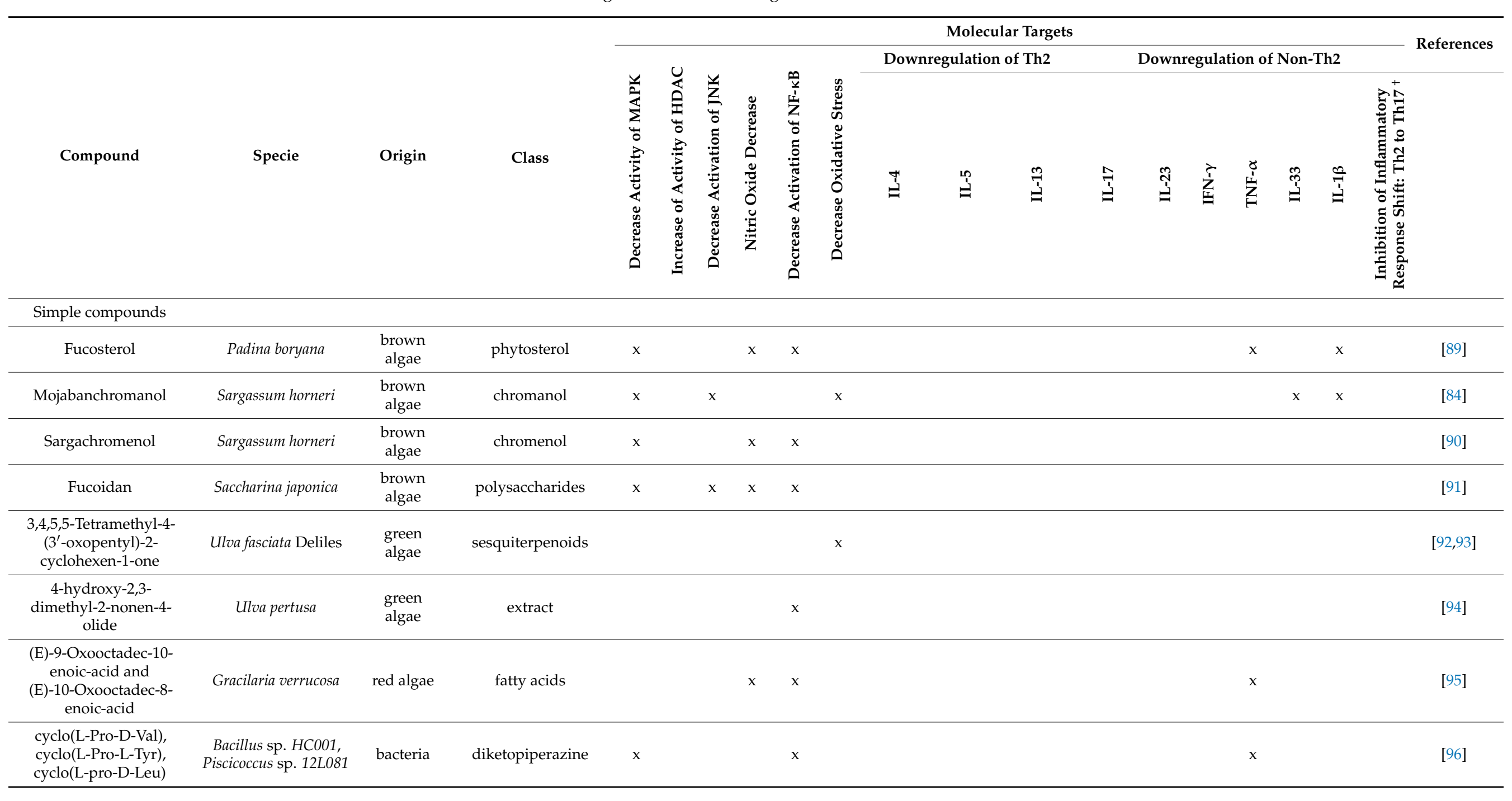


Table 3. Cont.

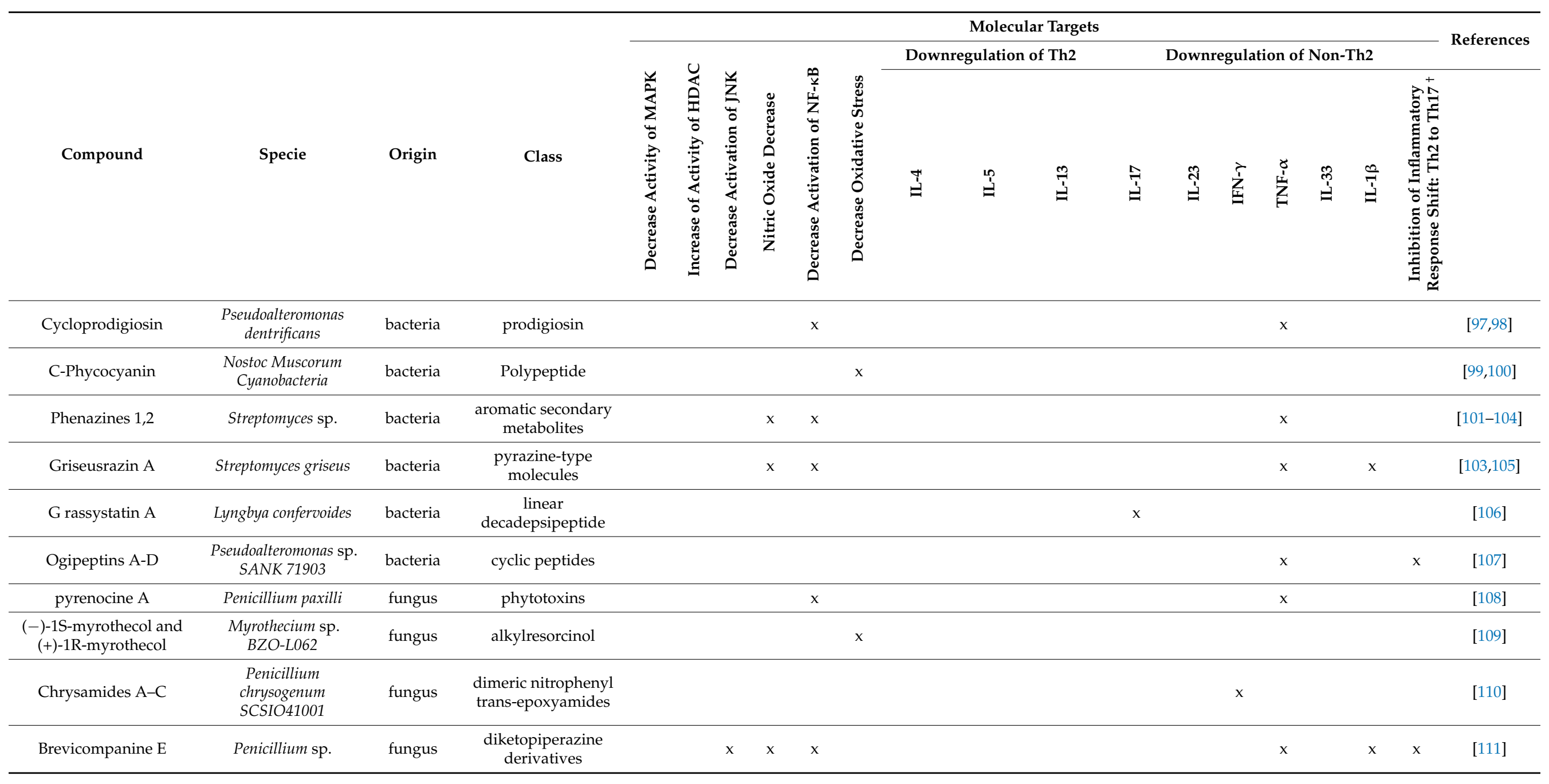


Table 3. Cont

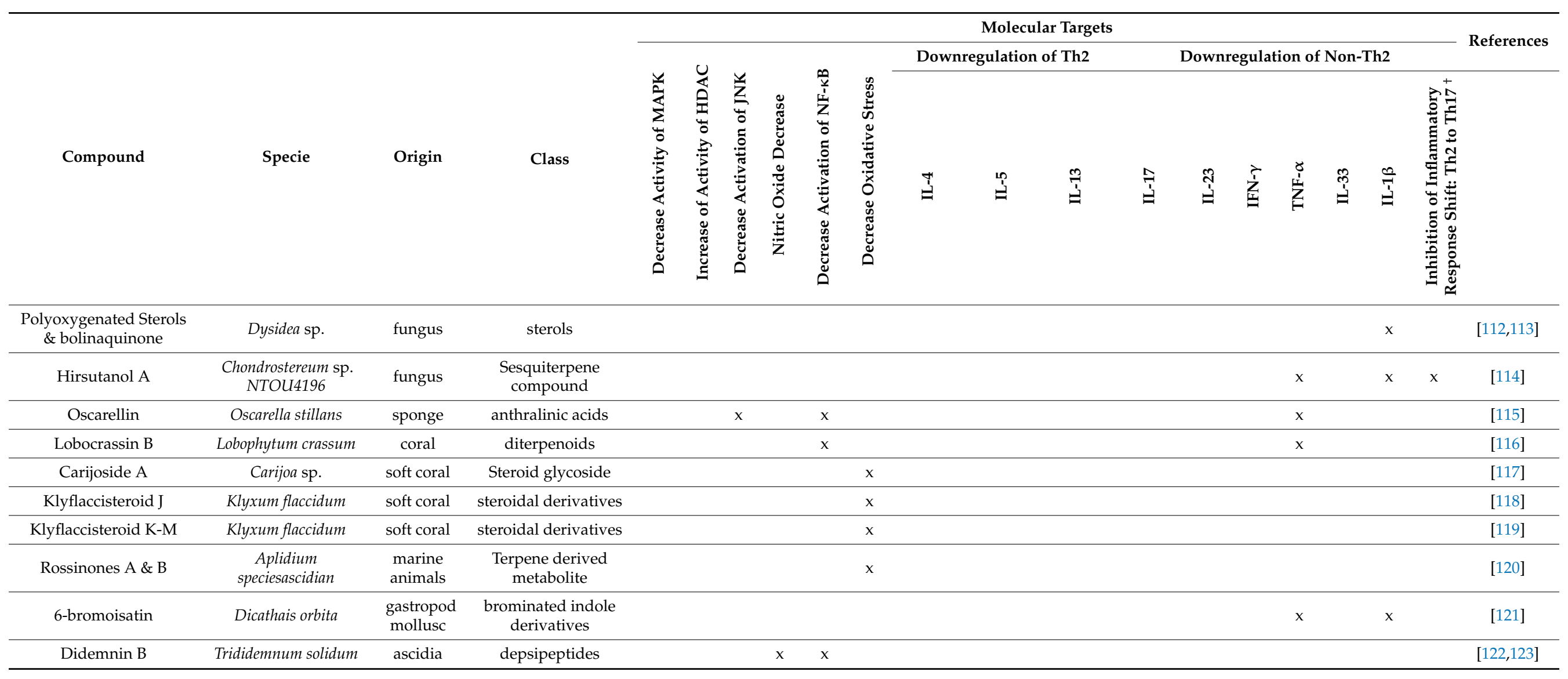


Table 3. Cont

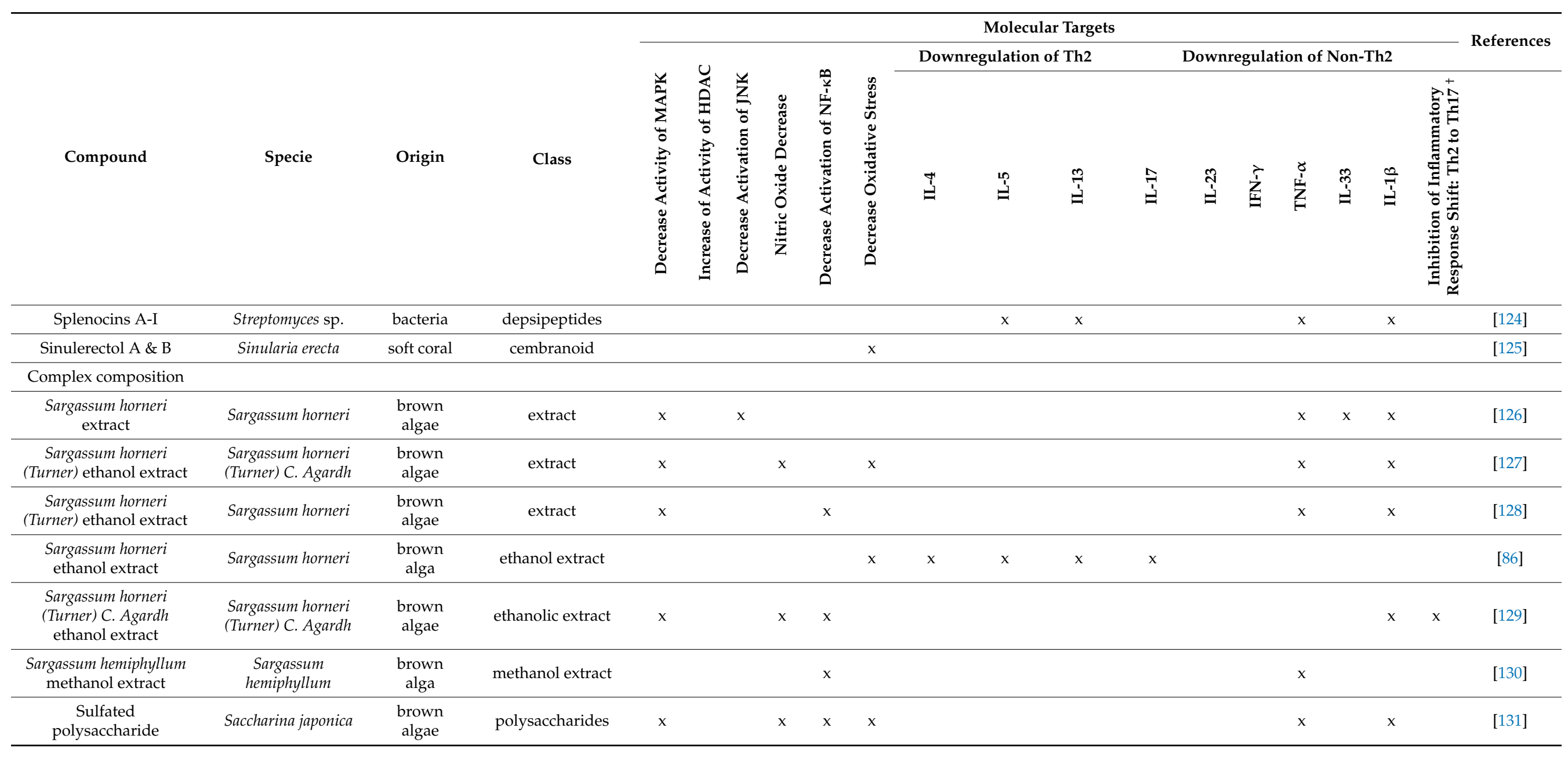


Table 3. Cont.

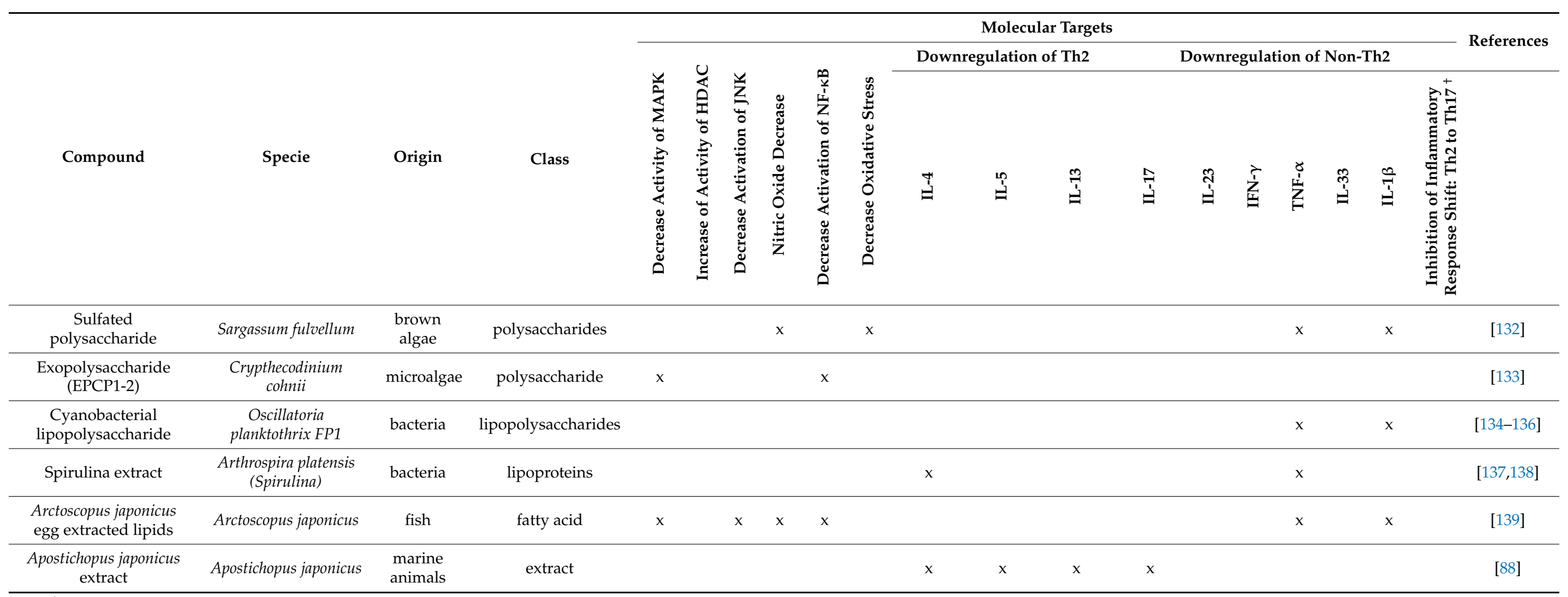

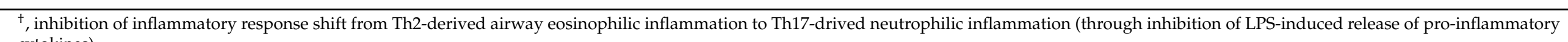
cytokines). 
Table 4. Chemical formula of marine drugs with potential use in glucocorticoid-resistant severe asthma.

\section{Compound}

Chemical Structure

fucosterol

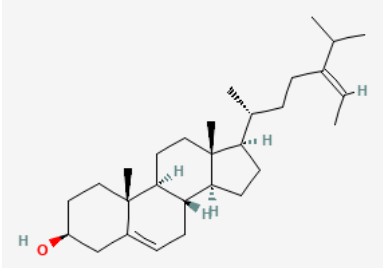

mojabanchromanol

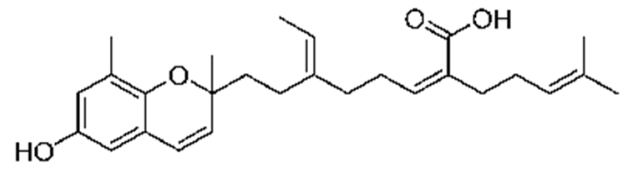

sargachromenol

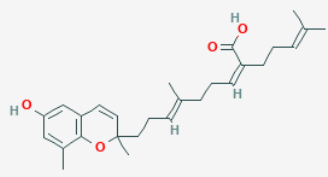

fucoidan

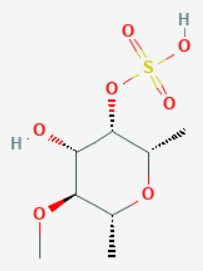

3,4,5,5-Tetramethyl-4-(3'-oxopentyl)-2-cyclohexen-1-one

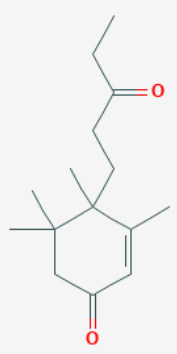


Table 4. Cont.

\section{Compound}

Chemical Structure

4-hydroxy-2,3-dimethyl-2-nonen-4-olide

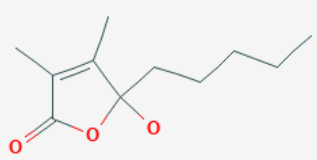

(E)-9-Oxooctadec-10-enoic-acid and

(E)-10-Oxooctadec-8-enoic-acid
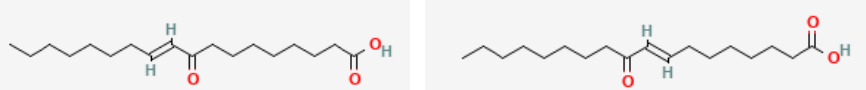

cyclo(L-Pro-D-Val), cyclo(L-Pro-L-Tyr), cyclo(L-pro-D-Leu)<smiles>CC(C)[C@H]1NC(=O)[C@@H]2CCCN2C1=O</smiles>

cyclo(L-Pro-D-Val) (1)<smiles>O=C1NC(Cc2ccc(O)cc2)C(=O)N2CCC[C@H]12</smiles>

cyclo(L-Pro-L-Tyr) (2)

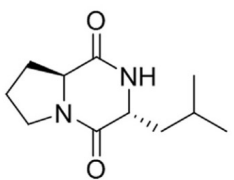

cyclo(L-Pro-D-Leu) (3)

cycloprodigiosin

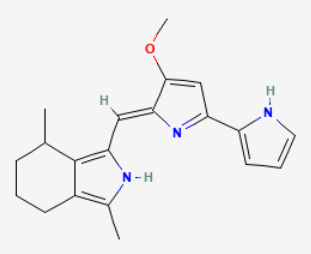

C-phycocyanin

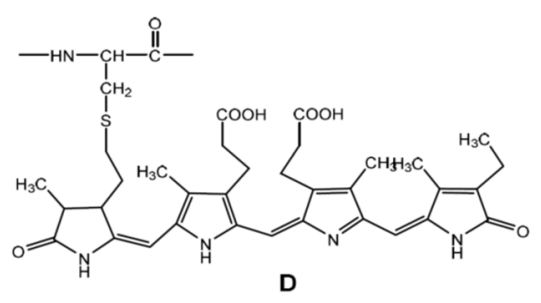


Table 4. Cont

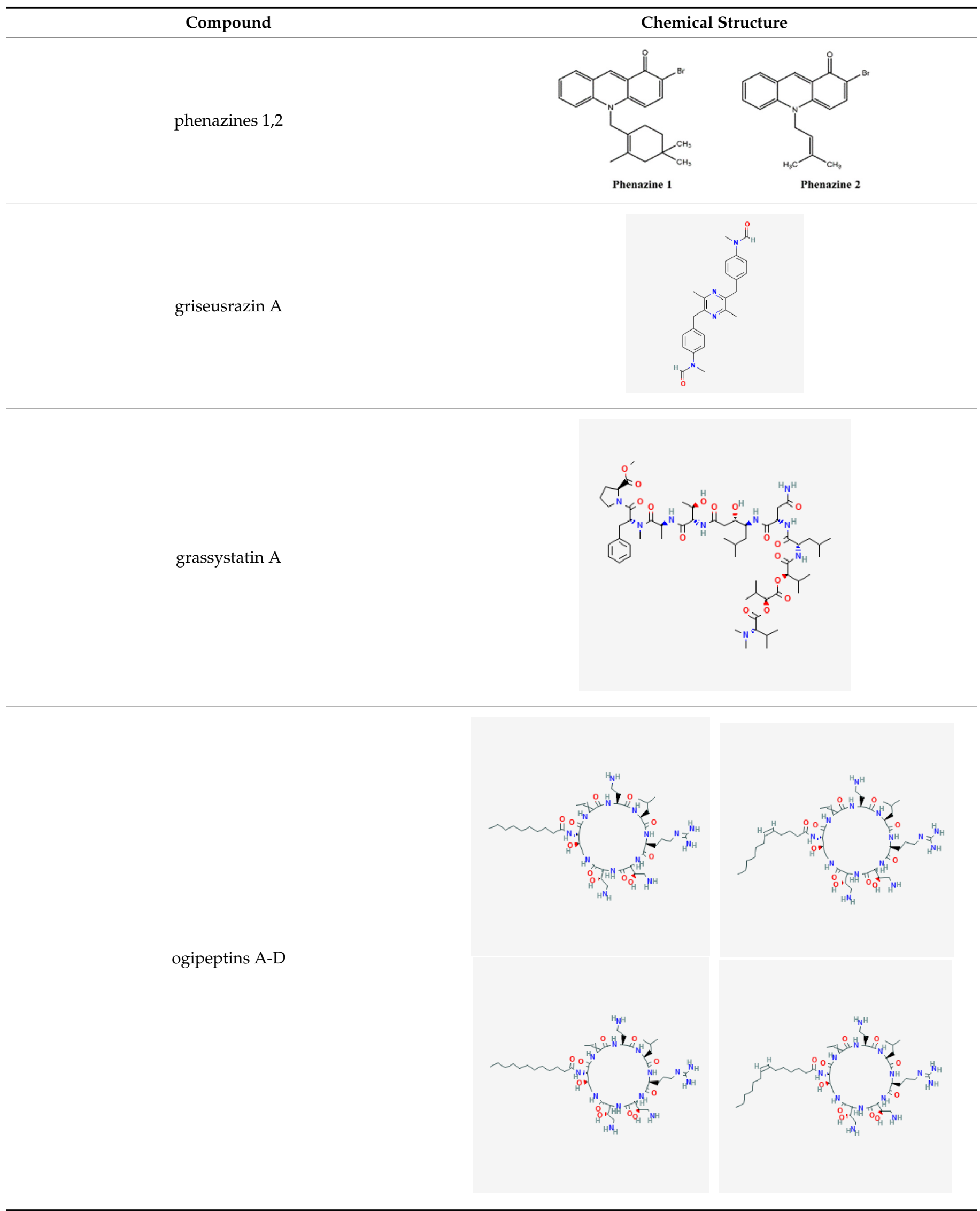


Table 4. Cont.

\section{Compound}

Chemical Structure

pyrenocine $\mathrm{A}$

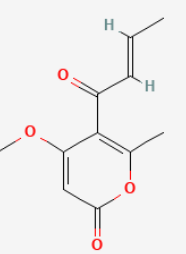

(-)-1S-myrothecol and (+)-1R-myrothecol<smiles>Cc1c(O)cc(C(=O)[C@H]2CCCO2)cc1O</smiles><smiles>Cc1c(O)cc(C(=O)[C@H]2CCCO2)cc1O</smiles>

chrysamides A-C

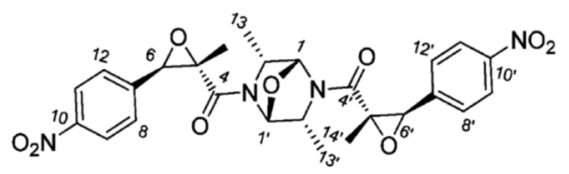<smiles>C[C@H]1CN(C(=O)[C@]2(C)OC2c2ccc([N+](=O)[O-])cc2)[C@@H]2C[C@@H]1CN2C(=O)[C@@]1(C)OC1c1ccc([N+](=O)[O-])cc1</smiles>

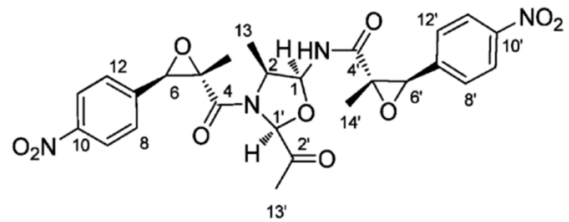

brevicompanine $\mathrm{E}$

polyoxygenated dysidea sterols
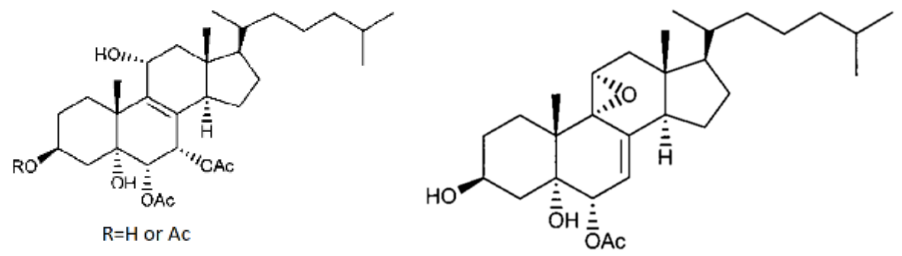
Table 4. Cont.

\section{Compound}

Chemical Structure

bolinaquinone

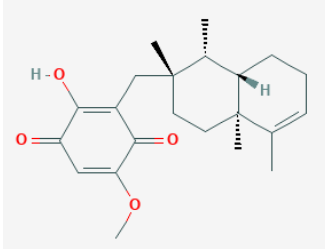

hirsutanol A

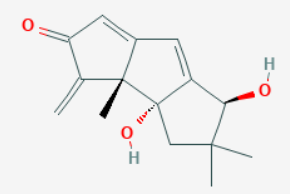

oscarellin

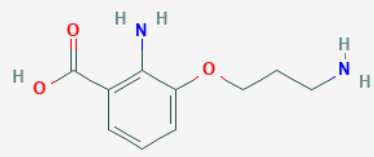

lobocrassin B

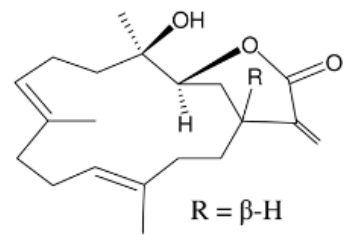

carijoside A

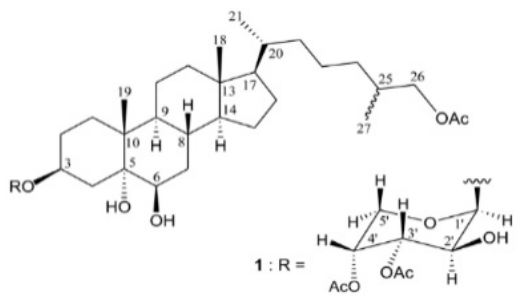

klyflaccisteroid J

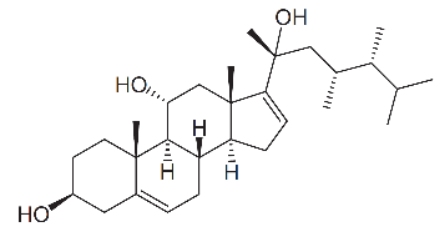


Table 4. Cont.

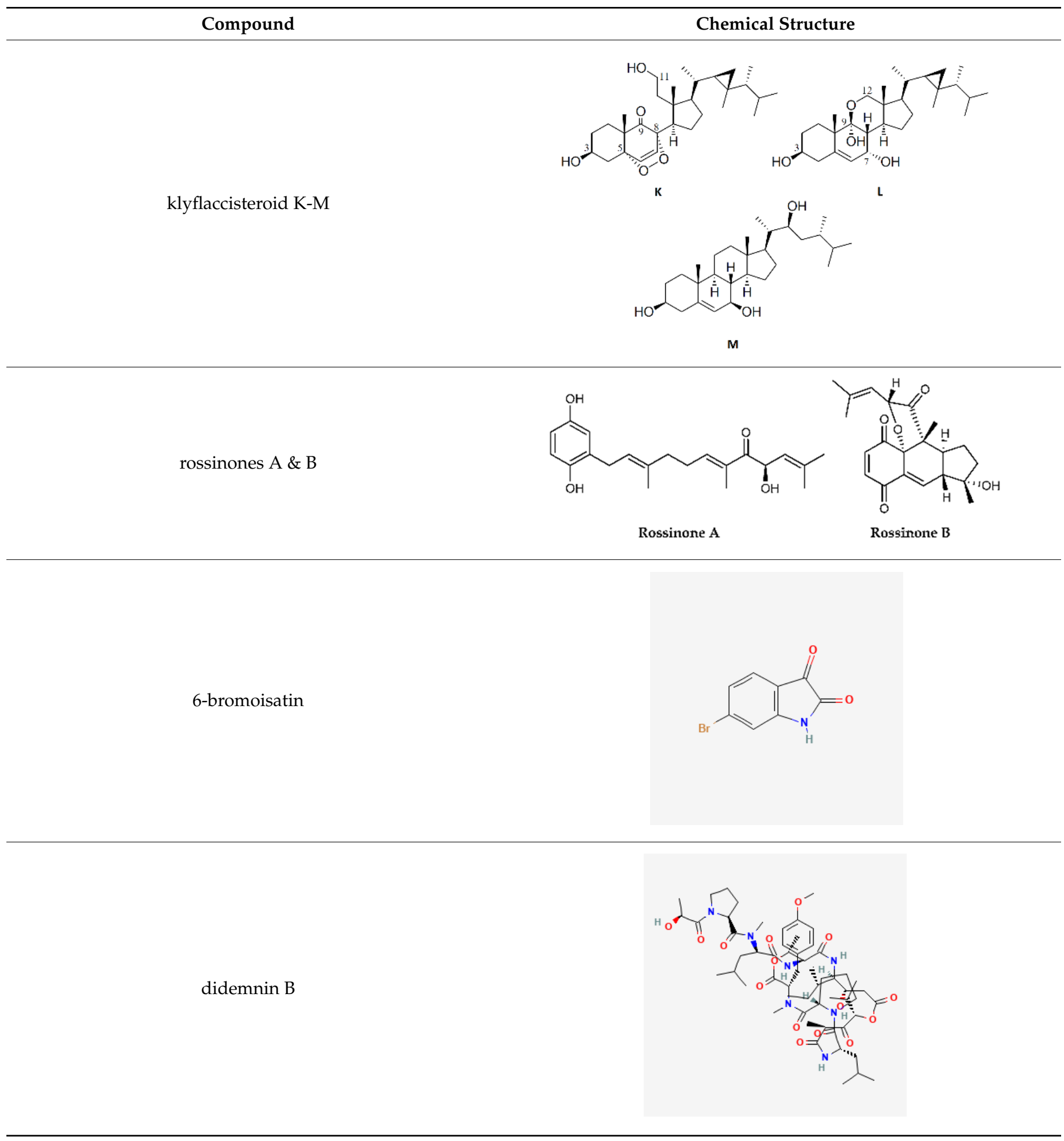


Table 4. Cont.

\section{Compound}

Compound

Fucoidan, purified from Saccharina japonica, reduced the production of NO, and downregulated the expression of the MAPK (including p38, ENK and JNK) and NF- $\mathrm{kB}$ (including p65 and IKK $\alpha / \mathrm{IKK} \beta$ ) signaling pathways in a zebrafish experiment [91].

Using free-radical-scavenging assays antioxidant properties were discovered for the sesquiterpenoids in green algae Ulva fasciata Deliles [92,93].

An extract from Korean marine alga Ulva pertusa, 4-hydroxy-2,3-dimethyl-2-nonen-4olide, moderately inhibited the release of the pro-inflammatory cytokines IL-12 p40 and IL-6 from bone marrow-derived dendritic cells, as well as signal transduction by inhibiting phosphorylation of NF-kB, and, thus, warranted further study to evaluate its potential as a "therapeutic agent for inflammation-associated maladies" [94].

Two fatty acids, (E)-9-Oxooctadec-10-enoic-acid and (E)-10-Oxooctadec-8-enoic-acid, isolated from Gracilaria verrucosa, inhibited the production of inflammatory biomarkers, including NO, IL-6, and TNF- $\alpha$, by suppressing the nuclear translocation of NF-kB and the phosphorylation of STAT1 in LPS-stimulated RAW264.7 cells [95].

Three diketopiperazine derivatives, cyclo(L-Pro-D-Val), cyclo(L-Pro-L-Tyr), and cyclo(Lpro-D-Leu), derived from two marine bacteria, Bacillus sp. HC001 and Piscicoccus sp. 12L081, demonstrated anti-inflammatory effects through the inhibition of p38 MAPK activation and the downregulation of TNF- $\alpha$, IL-6, NF-kB, and ERK1/2 [96].

Cycloprodigiosin, an analog of prodigiosin obtained from Pseudoalteromonas dentrificans, inhibited TNF- $\alpha$ induced NF-kB activation, in HeLa, U373, and COS7 cell lines $[97,98]$.

C-Phycocyanin from Nostoc Muscorum cyanobacteria is a pigment with antioxidant potential [99,100].

Pyrenocine A, produced from the marine-derived fungus Penicillium paxilli, produces immunosuppressive effects through the inhibition of pro-inflammatory mediators (TNF- $\alpha$ and PGE2) and inhibits the expression of genes related to NFKB activation in macrophages stimulated with LPS [108].

Two new components, (-)-1S-myrothecol and (+)-1R-myrothecol, isolated from the deep-sea fungus Myrothecium sp. BZO-L062, presented anti-inflammatory and antioxidant activities [109].

Oscarellin, an anthranilic acid derivative isolated from Oscarella stillans, a Philippine sponge, strongly inhibits LPS-induced TNF- $\alpha$ and IL-6 production in murine macrophage RAW264.7. These changes are associated with the inactivation of c-Jun NH2-terminal 
kinase (JNK), extracellular signal-regulated kinase (ERK), activator protein-1 (AP-1), and NF-kB, and the activation of activating transcription factor-3 (ATF-3) [115].

Lobocrassin B, an extract from the soft coral Lobophytum crissum, inhibited the production of TNF- $\alpha$ and NF- $\mathrm{KB}$, an important transcription factor responsible for cytokine production, in mouse dendritic cells [116].

Didemnin B (Depsipeptides) was extracted and isolated from Trididemnum solidum; it exhibited strong anti-inflammatory and immunosuppressive activity through the inhibition of iNOS and NF-kB $[122,123]$.

Sargassum horneri ethanol extract, from an edible brown marine algae, demonstrated anti-inflammatory effects mediated by the phosphorylation of MAPK p38, extracellular signal-regulated kinase 1/2 (Erk1/2), and c-JNK, to induce the particulate matter-induced mRNA expression of pro-inflammatory cytokines (IL-1 $\beta$, TNF- $\alpha$, IL-6), lung epithelial cell derived-chemokines (IL-8, MCP-1, and chemokine (CCL5), and to suppress the mRNA expression of particulate matter-induced pro-allergic cytokines thymic stromal lymphopoietin (TSLP) and IL-33 [126].

Sargassum horneri (Turner) C. Agardh ethanol extract (SHE), obtained from the brown algae Sargassum horneri, demonstrated anti-inflammatory and cytoprotective effects on macrophage cells as a model for alveolar lung cells, probably via the p38 MAPK pathway and Nrf2/HO-1 expression. The extract inhibited the production of inflammatory mediators (iNOS, COX-2, and PGE2) and pro-inflammatory cytokines (IL-1 $\beta$, IL-6, and TNF- $\alpha$ ) [127].

Another ethanol extract with a commercial grade of 70\%, separated from Sargassum horneri, demonstrated similar effects: it significantly repressed the secretions of inflammatory cytokines and reduced protein expression in PGE2, TNF- $\alpha$, IL-6, IL-1 $\beta$, NF- $\mathrm{BB}$, and MAPKs from PM-activated macrophages [128].

A sulfated polysaccharide with a sulfate content of $9.07 \%$ from Saccharina japonica showed significant inhibition of NO and PGE2 production via the downregulation of iNOS and COX-2 expression. The polysaccharide also suppressed TNF- $\alpha$ and (IL)-1 $\beta$ production via the NF- $\kappa$ B and MAPK signal pathways in LPS-induced RAW cells [131].

A sulfated polysaccharide isolated from Sargassum fulvellum demonstrated a significant and concentration-dependent decrease in the production levels of NO, TNF- $\alpha$, PGE2, IL-6, and IL-1 $\beta$ in LPS-treated RAW 264.7 macrophages [132].

The fatty acids from the Arctoscopus japonicus egg of a cold-water marine fish presented anti-inflammatory effects through the suppression of the expression of iNOS, COX-2, IL-1 $\beta$, IL-6, and TNF- $\alpha$, and a reduction in the phosphorylation levels of NF- $\mathrm{kB}$ p-65, p38, ERK1/2, and JNK, key components of the NF-KB and MAPK pathways [139].

\subsection{Cytokine Levels}

\subsubsection{Th2 Cytokines}

The whole culture extract of a marine-derived actinomycete strain, culture CNQ431, identified as a Streptomyces sp., demonstrated potent suppression of Th2 cytokines IL-5 and IL-13, but also the production of the dendritic cell-associated cytokines IL- 1 and TNF- $\alpha$, indicating immunosuppressive effects on both the APCs (i.e., dendritic cells) and the Th2 cells in a mouse splenocyte assay [124].

An ethanol extract from Sargassum horneri, obtained from a brown alga, was found to have antioxidant, anti-inflammatory, and anti-allergic effects in a BALB/c mouse model of asthma sensitized with ovalbumin. IL-4, IL-5, and IL-13 were found to be decreased in the lungs of PM-exacerbated asthmatic mice. Concomitantly, the Th17 cell response, the expression of responses of relevant effector cytokines, IL-17a and Th2/Th17, were also decreased [86].

A methanol extract of Sargassum hemiphyllum, a brown seaweed, inhibited the increase of TNF- $\alpha$-induced NF-kB protein levels, the transcription factor of TNF- $\alpha$, and IL- 8 and TNF- $\alpha$ release, suggesting an inhibitory effect on atopic allergic reactions [130]. 
Exopolysaccharide EPCP1-2, an extracellular polysaccharide extracted from Crypthecodinium cohnii, has significant potential to inhibit macrophage proliferation, as well as to downregulate the expression of TLR4, TAK1, MAPKs, and NF-KB protein. It acts as an anti-inflammatory agent through macrophage suppression on the RAW 264.7 macrophage cell line and is a potent regulatory MAPK, and NF-KB signaling pathways [133].

Spirulina extract (Immulina ${ }^{\circledR}$ ), a high-molecular-weight polysaccharide extract from the cyanobacterium Arthrospira platensis (Spirulina), showed anti-inflammatory and inhibitory effects in an induced allergic inflammatory response and on histamine release from RBL-2H3 mast cells. It also has the potential to inhibit the IgE-antigen-complex-induced production of TNF- $\alpha$, IL-4, leukotrienes, and histamine, and showed promising effects with respect to the relief of allergic rhinitis symptoms [137,138].

A component of this extract, $n$-hexane, a fatty-acid-rich fraction, ameliorated allergic airway inflammation in a mouse model of ovalbumin-induced asthma: eosinophil infiltration and goblet cell hyperplasia were significantly reduced around the airways, and the concentrations of Th2-related cytokines (IL-4, IL-5, and IL-13) and Th17-related cytokines (IL-17) were significantly decreased in the spleen and bronchoalveolar lavage fluid [88].

Phlorotannins isolated from brown algae, Eckolonia cava, exhibited anti-allergic activities through the inhibition of degranulation: the tested compounds suppressed the binding between IgE and FceRI receptors [140].

Reticulol, a polyketide isolated from Graphostroma sp. MCCC 3A00421 deep-sea hydrothermal sulfide deposits from the Atlantic Ocean, showed potent inhibition of degranulation with an IC50 value of $13.5 \mu \mathrm{M}$ [141].

Three compounds isolated from the deep-sea-derived marine Williamsia sp. MCCC 1A11233 (CDMW), CDMW-3, CDMW-5, and CDMW-15, demonstrated antiallergic activity due to the block of mast-cell-dependent passive cutaneous anaphylaxis in IgE-sensitized mice and to the decrease of degranulation and histamine release in immunoglobulin $\mathrm{E}$ (IgE)-mediated rat basophilic leukemia (RBL)-2H3 cells [142].

An extract of Apostichopus japonicus, obtained from a sea cucumber, showed antioxidant and anti-inflammation effects in mice with ovalbumin-induced asthma. The hyper-responsiveness of airways was significantly lower, the number of eosinophils in the lungs was decreased, and $T$ regulatory cells significantly increased in the mesenteric lymph nodes [143].

Peridinin and fucoxanthin, carotenoids isolated from Symbiodinium sp., a symbiotic dinoflagellate, and from Petalonia fascia, a brown alga, respectively, were shown to suppress allergic inflammatory responses through the inhibition of delayed-type hypersensitivity in mice, and to reduce the number of eosinophils in both the ear lobe and peripheral blood. The inhibitory effect of peridinin was higher than that of fucoxanthin [144].

\subsubsection{Th17/Non Th2 Cytokines}

Two novel phenazines, obtained from marine-derived Streptomyces sp., showed antiinflammatory potential and inhibited the production of LPS-induced NO, TNF- $\alpha$-induced NFkB activity [101-104].

Griseusrazin A, a pyrazine derivative produced from marine Streptomyces griseus, inhibited the production of pro-inflammatory cytokines, such as IL-1 $\beta$, IL-6, and TNF- $\alpha$, in LPS-stimulated cells and suppressed iNOS [103,105].

Grassystatin A, obtained from the cyanobacterium Lyngbya confervoides, inhibited the upregulation of IL-17 and interferon- $\gamma$ (INF- $\gamma$ ) in response to antigen presentation, reduced T cell proliferation in a dose-dependent manner, and inhibited the upregulation of IL-17 and IFN- $\gamma$ in response to antigen presentation [106].

Ogipeptins A-D, obtained from the culture broth of the Japanese marine Gramnegative bacterium Pseudoalteromonas sp. SANK 71903, decreased TNF- $\alpha$ release by human U937 monocytic cells [107]. 
Three chrysamides, A-C, dimeric nitrophenyl trans-epoxyamides obtained from the deep-sea-derived fungus, Penicillium chrysogenum SCSIO41001, suppressed the production of proinflammatory cytokine IL-17 [110].

Brevicompanine E, isolated from a deep ocean sediment-derived fungus, Penicillium sp., was found to inhibit LPS-induced TNF- $\alpha$, IL- $1 \beta$, iNOS and COX-2 production in microglia and LPS-induced I $\mathrm{BB} \alpha$ degradation, NF- $\mathrm{kB}$ nuclear translocation, and Akt, c-Jun NH2terminal kinase (JNK) phosphorylation [111].

Bolinaquinone, a polyoxygenated sterol derived from Dysidea sp., inhibited neutrophilic infiltration and IL-1 $\beta$ and PGE2 levels [112,113].

Hirsutanol A (HA), isolated from a red alga-derived fungus, Chondrostereum sp. NTOU4196, significantly attenuated the levels of TNF- $\alpha$, IL-6, and IL-1 $\beta$ in LPS-treated THP-1 cells [114].

Carijoside, a steroid glycoside extracted from Carijoa sp., inhibited the superoxide anion generation and elastase release by human neutrophils [117]. On the other hand, rossinones A and B, terpene-derived metabolites of the Aplidium speciesascidian family of Polyclinidae, inhibited only the superoxide production [120].

Klyflaccisteroid J, a steroid isolated from the Formosan soft coral Klyxum flaccidum, demonstrated suppression of N-formyl-methionyl-leucylphenyl-alanine/cytochalasin B (fMLP/CB)-induced superoxide anion generation and elastase release in human neutrophils in vitro [118]. New steroids, klyflaccisteroids K-M, also isolated from Klyxum flaccidum, demonstrated the suppression of superoxide anion generation and elastase release [119].

A brominated indol isolated form the gastropod mollusk Dicathais orbita, 6-bromoisatin, inhibited inflammation in a murine model of LPS-induced acute lung injury by significantly reducing TNF- $\alpha$ and IL-1 $\beta$ production and associated lung damage [121].

Sinulerectol A and Sinulerectol B, as extracts isolated from the marine soft coral Sinularia erecta, showed anti-inflammatory activities in neutrophil pro-inflammatory responses [125].

Sargassum horneri (Turner), a C. Agardh ethanolic extract with $70 \%$ ethanol lyophilized at $-40{ }^{\circ} \mathrm{C}$, obtained from a brown alga, showed antioxidant and anti-inflammatory effects through a dose-dependent reduction of the mRNA level of cytokines, including IL-1 $\beta$, and pro-inflammatory genes, such as iNOS and COX-2, in LPS-stimulated macrophage activation. In addition, the anti-inflammatory effects were obtained by inhibiting ERK, p-p38 and NF- $\kappa B$ phosphorylation and by the release of IL-1 $\beta$ in LPS-stimulated macrophages [129].

A cyanobacterial lipopolysaccharide, isolated from Oscillatoria planktothrix FP1, demonstrated anti-inflammatory effects through the inhibition of LPS-induced IL- $1 \beta$, TNF- $\alpha$, and IL-8 production [134-136].

\section{Conclusions}

In recent years, efforts have been made to understand the mechanisms underlying GC resistance. To overcome GC resistance, which is frequently associated with high doses of GC treatment, there is an urgent need for more specific targeted therapies. Natural compounds have been demonstrated to be effective against various pathological mechanisms through a variety of pathways. Some of these mechanisms were also shown to be involved in GC resistance. This paper reviewed the marine compounds potentially acting on the mechanisms involved in GC-resistant severe asthma. The article provided a basis for the development of effective marine-derived drugs as new and safe sources for the potential treatment of glucocorticoid-resistant severe asthma.

Author Contributions: Conceptualization, methodology, writing-original draft preparation, and writing-review and editing, C.M.G., A.G.V., C.S.S., S.A.A. and P.P. All authors have read and agreed to the published version of the manuscript.

Funding: Doctoral Scholarship from Grigore T. Popa University of Medicine and Pharmacy of Iași, Romania (for A.G.V.).

Institutional Review Board Statement: Not applicable. 
Informed Consent Statement: Not applicable.

Conflicts of Interest: The authors declare no conflict of interest.

\section{References}

1. Borna, E.; Nwaru, B.I.; Bjerg, A.; Mincheva, R.; Rådinger, M.; Lundbäck, B.; Ekerljung, L. Changes in the Prevalence of Asthma and Respiratory Symptoms in Western Sweden between 2008 and 2016. Allergy 2019, 74, 1703-1715. [CrossRef]

2. Hekking, P.-P.W.; Wener, R.R.; Amelink, M.; Zwinderman, A.H.; Bouvy, M.L.; Bel, E.H. The Prevalence of Severe Refractory Asthma. J. Allergy Clin. Immunol. 2015, 135, 896-902. [CrossRef]

3. Chung, K.F.; Wenzel, S.E.; Brozek, J.L.; Bush, A.; Castro, M.; Sterk, P.J.; Adcock, I.M.; Bateman, E.D.; Bel, E.H.; Bleecker, E.R.; et al. International ERS/ATS Guidelines on Definition, Evaluation and Treatment of Severe Asthma. Eur. Respir. J. 2014, 43, 343-373. [CrossRef]

4. $\quad$ O’Neill, S.; Sweeney, J.; Patterson, C.C.; Menzies-Gow, A.; Niven, R.; Mansur, A.H.; Bucknall, C.; Chaudhuri, R.; Thomson, N.C.; Brightling, C.E.; et al. The Cost of Treating Severe Refractory Asthma in the UK: An Economic Analysis from the British Thoracic Society Difficult Asthma Registry. Thorax 2015, 70, 376-378. [CrossRef]

5. Global Initiative for Asthma. Available online: https://ginasthma.org/ (accessed on 27 September 2021).

6. Carmichael, J.; Paterson, I.C.; Diaz, P.; Crompton, G.K.; Kay, A.B.; Grant, I.W. Corticosteroid Resistance in Chronic Asthma. Br. Med. J. (Clin. Res. Ed.) 1981, 282, 1419-1422. [CrossRef] [PubMed]

7. Barnes, P.J.; Greening, A.P.; Crompton, G.K. Glucocorticoid Resistance in Asthma. Am. J. Respir. Crit. Care Med. 1995, 152 Pt 2 , S125-S140. [CrossRef] [PubMed]

8. Löwhagen, O. Diagnosis of Asthma-New Theories. J. Asthma 2015, 52, 538-544. [CrossRef]

9. Barreca, M.; Spanò, V.; Montalbano, A.; Cueto, M.; Díaz Marrero, A.R.; Deniz, I.; Erdoğan, A.; Lukić Bilela, L.; Moulin, C.; Taffin-de-Givenchy, E.; et al. Marine Anticancer Agents: An Overview with a Particular Focus on Their Chemical Classes. Mar. Drugs 2020, 18, 619. [CrossRef]

10. Chen, G.; Seukep, A.J.; Guo, M. Recent Advances in Molecular Docking for the Research and Discovery of Potential Marine Drugs. Mar. Drugs 2020, 18, 545. [CrossRef] [PubMed]

11. Grosso, C.; Valentão, P.; Ferreres, F.; Andrade, P.B. Bioactive Marine Drugs and Marine Biomaterials for Brain Diseases. Mar. Drugs 2014, 12, 2539-2589. [CrossRef]

12. Mayer, A.M.S.; Guerrero, A.J.; Rodríguez, A.D.; Taglialatela-Scafati, O.; Nakamura, F.; Fusetani, N. Marine Pharmacology in 2014-2015: Marine Compounds with Antibacterial, Antidiabetic, Antifungal, Anti-Inflammatory, Antiprotozoal, Antituberculosis, Antiviral, and Anthelmintic Activities; Affecting the Immune and Nervous Systems, and Other Miscellaneous Mechanisms of Action. Mar. Drugs 2019, 18, 5. [CrossRef]

13. Mayer, A.M.S.; Guerrero, A.J.; Rodríguez, A.D.; Taglialatela-Scafati, O.; Nakamura, F.; Fusetani, N. Marine Pharmacology in 2016-2017: Marine Compounds with Antibacterial, Antidiabetic, Antifungal, Anti-Inflammatory, Antiprotozoal, Antituberculosis and Antiviral Activities; Affecting the Immune and Nervous Systems, and Other Miscellaneous Mechanisms of Action. Mar. Drugs 2021, 19, 49. [CrossRef] [PubMed]

14. Yun, C.W.; Kim, H.J.; Lee, S.H. Therapeutic Application of Diverse Marine-Derived Natural Products in Cancer Therapy. Anticancer Res. 2019, 39, 5261-5284. [CrossRef]

15. Zhou, J.-B.; Luo, R.; Zheng, Y.-L.; Pang, J.-Y. Recent Advances in the Discovery and Development of Marine Natural Products with Cardiovascular Pharmacological Effects. Mini Rev. Med. Chem. 2018, 18, 527-550. [CrossRef] [PubMed]

16. Bilal, M.; Qindeel, M.; Nunes, L.V.; Duarte, M.T.S.; Ferreira, L.F.R.; Soriano, R.N.; Iqbal, H.M.N. Marine-Derived Biologically Active Compounds for the Potential Treatment of Rheumatoid Arthritis. Mar. Drugs 2021, 19, 10. [CrossRef]

17. Bălașa, A.F.; Chircov, C.; Grumezescu, A.M. Marine Biocompounds for Neuroprotection-A Review. Mar. Drugs 2020, 18, 290. [CrossRef]

18. Wenzel, S.E. Asthma Phenotypes: The Evolution from Clinical to Molecular Approaches. Nat. Med. 2012, 18, 716-725. [CrossRef]

19. Chambers, E.S.; Nanzer, A.M.; Pfeffer, P.E.; Richards, D.F.; Timms, P.M.; Martineau, A.R.; Griffiths, C.J.; Corrigan, C.J.; Hawrylowicz, C.M. Distinct Endotypes of Steroid-Resistant Asthma Characterized by IL-17Ahigh and IFN-Гhigh Immunophenotypes: Potential Benefits of Calcitriol. J. Allergy Clin. Immunol. 2015, 136, 628-637.e4. [CrossRef] [PubMed]

20. Keenan, C.R.; Radojicic, D.; Li, M.; Radwan, A.; Stewart, A.G. Heterogeneity in Mechanisms Influencing Glucocorticoid Sensitivity: The Need for a Systems Biology Approach to Treatment of Glucocorticoid-Resistant Inflammation. Pharmacol. Ther. 2015, 150, 81-93. [CrossRef]

21. Barnes, P.J.; Adcock, I.M. Glucocorticoid Resistance in Inflammatory Diseases. Lancet 2009, 373, 1905-1917. [CrossRef]

22. Barnes, P.J. Corticosteroid Resistance in Patients with Asthma and Chronic Obstructive Pulmonary Disease. J. Allergy Clin. Immunol. 2013, 131, 636-645. [CrossRef] [PubMed]

23. Keenan, C.R.; Salem, S.; Fietz, E.R.; Gualano, R.C.; Stewart, A.G. Glucocorticoid-Resistant Asthma and Novel Anti-Inflammatory Drugs. Drug Discov. Today 2012, 17, 1031-1038. [CrossRef]

24. Scheschowitsch, K.; Leite, J.A.; Assreuy, J. New Insights in Glucocorticoid Receptor Signaling-More Than Just a Ligand-Binding Receptor. Front. Endocrinol. (Lausanne) 2017, 8, 16. [CrossRef]

25. Oakley, R.H.; Sar, M.; Cidlowski, J.A. The Human Glucocorticoid Receptor $\beta$ Isoform: Expression, Biochemical Properties, and Putative Function. J. Biol. Chem. 1996, 271, 9550-9559. [CrossRef] 
26. Charmandari, E.; Chrousos, G.P.; Ichijo, T.; Bhattacharyya, N.; Vottero, A.; Souvatzoglou, E.; Kino, T. The Human Glucocorticoid Receptor (HGR) $\beta$ Isoform Suppresses the Transcriptional Activity of HGR $\alpha$ by Interfering with Formation of Active Coactivator Complexes. Mol. Endocrinol. 2005, 19, 52-64. [CrossRef]

27. Stahn, C.; Buttgereit, F. Genomic and Nongenomic Effects of Glucocorticoids. Nat. Rev. Rheumatol. 2008, 4, 525-533. [CrossRef] [PubMed]

28. Galigniana, M.D.; Echeverría, P.C.; Erlejman, A.G.; Piwien-Pilipuk, G. Role of Molecular Chaperones and TPR-Domain Proteins in the Cytoplasmic Transport of Steroid Receptors and Their Passage through the Nuclear Pore. Nucleus 2010, 1, 299-308. [CrossRef]

29. Galon, J.; Franchimont, D.; Hiroi, N.; Frey, G.; Boettner, A.; Ehrhart-Bornstein, M.; O'Shea, J.J.; Chrousos, G.P.; Bornstein, S.R. Gene Profiling Reveals Unknown Enhancing and Suppressive Actions of Glucocorticoids on Immune Cells. FASEB J. 2002, 16, 61-71. [CrossRef] [PubMed]

30. Dennis, M.; Itkin, I.H. Effectiveness and Complications of Aerosol Dexamethasone Phosphate in Severe Asthma. J. Allergy 1964, 35, 70-76. [CrossRef]

31. Schwiebert, L.A.; Beck, L.A.; Stellato, C.; Bickel, C.A.; Bochner, B.S.; Schleimer, R.P. Glucocorticosteroid Inhibition of Cytokine Production: Relevance to Antiallergic Actions. J. Allergy Clin. Immunol. 1996, 97 Pt 2, 143-152. [CrossRef]

32. Alangari, A.A. Genomic and Non-Genomic Actions of Glucocorticoids in Asthma. Ann. Thorac. Med. 2010, 5, 133. [CrossRef]

33. Hirst, S.J.; Lee, T.H. Airway Smooth Muscle as a Target of Glucocorticoid Action in the Treatment of Asthma. Am. J. Respir. Crit. Care Med. 1998, 158 (Suppl. S2), S201-S206. [CrossRef]

34. Zhou, J.; Liu, D.-F.; Liu, C.; Kang, Z.-M.; Shen, X.-H.; Chen, Y.-Z.; Xu, T.; Jiang, C.-L. Glucocorticoids Inhibit Degranulation of Mast Cells in Allergic Asthma via Nongenomic Mechanism. Allergy 2008, 63, 1177-1185. [CrossRef]

35. Ayroldi, E.; Cannarile, L.; Migliorati, G.; Nocentini, G.; Delfino, D.V.; Riccardi, C. Mechanisms of the Anti-Inflammatory Effects of Glucocorticoids: Genomic and Nongenomic Interference with MAPK Signaling Pathways. FASEB J. 2012, 26, 4805-4820. [CrossRef] [PubMed]

36. Tantisira, K.G.; Lasky-Su, J.; Harada, M.; Murphy, A.; Litonjua, A.A.; Himes, B.E.; Lange, C.; Lazarus, R.; Sylvia, J.; Klanderman, B.; et al. Genomewide Association between GLCCI1 and Response to Glucocorticoid Therapy in Asthma. N. Engl. J. Med. 2011, 365, 1173-1183. [CrossRef]

37. Keskin, O.; Uluca, Ü.; Birben, E.; Coşkun, Y.; Ozkars, M.Y.; Keskin, M.; Kucukosmanoglu, E.; Kalayci, O. Genetic Associations of the Response to Inhaled Corticosteroids in Children during an Asthma Exacerbation. Pediatr. Allergy Immunol. 2016, 27, 507-513. [CrossRef]

38. Hu, C.; Xun, Q.; Li, X.; He, R.; Lu, R.; Zhang, S.; Hu, X.; Feng, J. GLCCI1 Variation Is Associated with Asthma Susceptibility and Inhaled Corticosteroid Response in a Chinese Han Population. Arch. Med. Res. 2016, 47, 118-125. [CrossRef] [PubMed]

39. Weigel, N.L.; Moore, N.L. Steroid Receptor Phosphorylation: A Key Modulator of Multiple Receptor Functions. Mol. Endocrinol. 2007, 21, 2311-2319. [CrossRef]

40. Adcock, I.M.; Lane, S.J.; Brown, C.R.; Lee, T.H.; Barnes, P.J. Abnormal Glucocorticoid Receptor-Activator Protein 1 Interaction in Steroid-Resistant Asthma. J. Exp. Med. 1995, 182, 1951-1958. [CrossRef] [PubMed]

41. Ramamoorthy, S.; Cidlowski, J.A. Ligand-Induced Repression of the Glucocorticoid Receptor Gene Is Mediated by an NCoR1 Repression Complex Formed by Long-Range Chromatin Interactions with Intragenic Glucocorticoid Response Elements. Mol. Cell. Biol. 2013, 33, 1711-1722. [CrossRef]

42. Vazquez-Tello, A.; Halwani, R.; Hamid, Q.; Al-Muhsen, S. Glucocorticoid Receptor-Beta up-Regulation and Steroid Resistance Induction by IL-17 and IL-23 Cytokine Stimulation in Peripheral Mononuclear Cells. J. Clin. Immunol. 2013, 33, 466-478. [CrossRef]

43. Irusen, E.; Matthews, J.G.; Takahashi, A.; Barnes, P.J.; Chung, K.F.; Adcock, I.M. P38 Mitogen-Activated Protein Kinase-Induced Glucocorticoid Receptor Phosphorylation Reduces Its Activity: Role in Steroid-Insensitive Asthma. J. Allergy Clin. Immunol. 2002, 109, 649-657. [CrossRef] [PubMed]

44. Adcock, I.M. Glucocorticoid-Regulated Transcription Factors. Pulm. Pharmacol. Ther. 2001, 14, 211-219. [CrossRef]

45. Leung, D.Y.; Martin, R.J.; Szefler, S.J.; Sher, E.R.; Ying, S.; Kay, A.B.; Hamid, Q. Dysregulation of Interleukin 4, Interleukin 5, and Interferon Gamma Gene Expression in Steroid-Resistant Asthma. J. Exp. Med. 1995, 181, 33-40. [CrossRef] [PubMed]

46. Gurgone, D.; McShane, L.; McSharry, C.; Guzik, T.J.; Maffia, P. Cytokines at the Interplay Between Asthma and Atherosclerosis? Front. Pharmacol. 2020, 11, 166. [CrossRef] [PubMed]

47. Peters, M.C.; Wenzel, S.E. Intersection of Biology and Therapeutics: Type 2 Targeted Therapeutics for Adult Asthma. Lancet 2020, 395, 371-383. [CrossRef]

48. Ito, K.; Yamamura, S.; Essilfie-Quaye, S.; Cosio, B.; Ito, M.; Barnes, P.J.; Adcock, I.M. Histone Deacetylase 2-Mediated Deacetylation of the Glucocorticoid Receptor Enables NF-KB Suppression. J. Exp. Med. 2005, 203, 7-13. [CrossRef]

49. Bhavsar, P.; Hew, M.; Khorasani, N.; Torrego, A.; Barnes, P.J.; Adcock, I.; Chung, K.F. Relative Corticosteroid Insensitivity of Alveolar Macrophages in Severe Asthma Compared with Non-Severe Asthma. Thorax 2008, 63, 784-790. [CrossRef] [PubMed]

50. Patel, N.R.; Cunoosamy, D.M.; Fagerås, M.; Taib, Z.; Asimus, S.; Hegelund-Myrbäck, T.; Lundin, S.; Pardali, K.; Kurian, N.; Ersdal, E.; et al. The Development of AZD7624 for Prevention of Exacerbations in COPD: A Randomized Controlled Trial. Int. J. Chron. Obstruct. Pulm. Dis. 2018, 13, 1009-1019. [CrossRef]

51. Li, L.; Leung, D.Y.M.; Goleva, E. Activated P38 MAPK in Peripheral Blood Monocytes of Steroid Resistant Asthmatics. PLoS ONE 2015, 10, e0141909. [CrossRef] 
52. Spears, M.; Donnelly, I.; Jolly, L.; Brannigan, M.; Ito, K.; McSharry, C.; Lafferty, J.; Chaudhuri, R.; Braganza, G.; Adcock, I.M.; et al. Effect of Low-Dose Theophylline plus Beclometasone on Lung Function in Smokers with Asthma: A Pilot Study. Eur. Respir. J. 2009, 33, 1010-1017. [CrossRef] [PubMed]

53. Mercado, N.; Hakim, A.; Kobayashi, Y.; Meah, S.; Usmani, O.S.; Chung, K.F.; Barnes, P.J.; Ito, K. Restoration of Corticosteroid Sensitivity by P38 Mitogen Activated Protein Kinase Inhibition in Peripheral Blood Mononuclear Cells from Severe Asthma. PLoS ONE 2012, 7, e41582. [CrossRef]

54. Bi, J.; Min, Z.; Yuan, H.; Jiang, Z.; Mao, R.; Zhu, T.; Liu, C.; Zeng, Y.; Song, J.; Du, C.; et al. PI3K Inhibitor Treatment Ameliorates the Glucocorticoid Insensitivity of PBMCs in Severe Asthma. Clin. Transl. Med. 2020, 9, 22. [CrossRef]

55. Ito, K.; Lim, S.; Caramori, G.; Chung, K.F.; Barnes, P.J.; Adcock, I.M. Cigarette Smoking Reduces Histone Deacetylase 2 Expression, Enhances Cytokine Expression, and Inhibits Glucocorticoid Actions in Alveolar Macrophages. FASEB J. 2001, 15, 1110-1112. [CrossRef]

56. Zuccaro, L.; Cox, A.; Pray, C.; Radford, K.; Novakowski, K.; Dorrington, M.; Surette, M.G.; Bowdish, D.; Nair, P. Histone Deacetylase Activity and Recurrent Bacterial Bronchitis in Severe Eosinophilic Asthma. Allergy 2016, 71, 571-575. [CrossRef]

57. Essilfie, A.-T.; Simpson, J.L.; Horvat, J.C.; Preston, J.A.; Dunkley, M.L.; Foster, P.S.; Gibson, P.G.; Hansbro, P.M. Haemophilus influenzae Infection Drives IL-17-Mediated Neutrophilic Allergic Airways Disease. PLoS Pathog. 2011, 7, e1002244. [CrossRef]

58. Yang, X.; Wang, Y.; Zhao, S.; Wang, R.; Wang, C. Long-Term Exposure to Low-Dose Haemophilus influenzae during Allergic Airway Disease Drives a Steroid-Resistant Neutrophilic Inflammation and Promotes Airway Remodeling. Oncotarget 2018, 9, 24898-24913. [CrossRef] [PubMed]

59. Paróczai, D.; Mosolygó, T.; Kókai, D.; Endrész, V.; Virok, D.P.; Somfay, A.; Burián, K. Chlamydia Pneumoniae Influence on Cytokine Production in Steroid-Resistant and Steroid-Sensitive Asthmatics. Pathogens 2020, 9, 112. [CrossRef] [PubMed]

60. Beale, J.; Jayaraman, A.; Jackson, D.J.; Macintyre, J.D.R.; Edwards, M.R.; Walton, R.P.; Zhu, J.; Ching, Y.M.; Shamji, B.; Edwards, M.; et al. Rhinovirus-Induced IL-25 in Asthma Exacerbation Drives Type 2 Immunity and Allergic Pulmonary Inflammation. Sci. Transl. Med. 2014, 6, 256ra134. [CrossRef]

61. Papi, A.; Contoli, M.; Adcock, I.M.; Bellettato, C.; Padovani, A.; Casolari, P.; Stanciu, L.A.; Barnes, P.J.; Johnston, S.L.; Ito, K.; et al. Rhinovirus Infection Causes Steroid Resistance in Airway Epithelium through Nuclear Factor KB and C-Jun N-Terminal Kinase Activation. J. Allergy Clin. Immunol. 2013, 132, 1075-1085. [CrossRef]

62. Reidl, J.; Monsó, E. Glucocorticoids and Antibiotics, How Do They Get Together? EMBO Mol. Med. 2015, 7, 992-993. [CrossRef]

63. Shimizu, K.; Konno, S.; Ozaki, M.; Umezawa, K.; Yamashita, K.; Todo, S.; Nishimura, M. Dehydroxymethylepoxyquinomicin (DHMEQ), a Novel NF-KappaB Inhibitor, Inhibits Allergic Inflammation and Airway Remodelling in Murine Models of Asthma. Clin. Exp. Allergy 2012, 42, 1273-1281. [CrossRef] [PubMed]

64. Newton, R.; Holden, N.S.; Catley, M.C.; Oyelusi, W.; Leigh, R.; Proud, D.; Barnes, P.J. Repression of Inflammatory Gene Expression in Human Pulmonary Epithelial Cells by Small-Molecule IkB Kinase Inhibitors. J. Pharmacol. Exp. Ther. 2007, 321, 734-742. [CrossRef] [PubMed]

65. Castanhinha, S.; Sherburn, R.; Walker, S.; Gupta, A.; Bossley, C.J.; Buckley, J.; Ullmann, N.; Grychtol, R.; Campbell, G.; Maglione, M.; et al. Pediatric Severe Asthma with Fungal Sensitization Is Mediated by Steroid-Resistant IL-33. J. Allergy Clin. Immunol. 2015, 136, 312-322.e7. [CrossRef] [PubMed]

66. Li, J.J.; Tay, H.L.; Maltby, S.; Xiang, Y.; Eyers, F.; Hatchwell, L.; Zhou, H.; Toop, H.D.; Morris, J.C.; Nair, P.; et al. MicroRNA-9 Regulates Steroid-Resistant Airway Hyperresponsiveness by Reducing Protein Phosphatase 2A Activity. J. Allergy Clin. Immunol. 2015, 136, 462-473. [CrossRef] [PubMed]

67. Britt, R.D.; Thompson, M.A.; Sasse, S.; Pabelick, C.M.; Gerber, A.N.; Prakash, Y.S. Th1 Cytokines TNF- $\alpha$ and IFN- $\gamma$ Promote Corticosteroid Resistance in Developing Human Airway Smooth Muscle. Am. J. Physiol.-Lung Cell. Mol. Physiol. 2019, 316, L71-L81. [CrossRef]

68. Ismaili, N.; Garabedian, M.J. Modulation of Glucocorticoid Receptor Function via Phosphorylation. Ann. N. Y. Acad. Sci. 2004, 1024, 86-101. [CrossRef] [PubMed]

69. Galigniana, M.D.; Piwien-Pilipuk, G.; Assreuy, J. Inhibition of Glucocorticoid Receptor Binding by Nitric Oxide. Mol. Pharmacol. 1999, 55, 317-323. [CrossRef]

70. Kim, R.Y.; Horvat, J.C.; Pinkerton, J.W.; Starkey, M.R.; Essilfie, A.T.; Mayall, J.R.; Nair, P.M.; Hansbro, N.G.; Jones, B.; Haw, T.J.; et al. MicroRNA-21 Drives Severe, Steroid-Insensitive Experimental Asthma by Amplifying Phosphoinositide 3-Kinase-Mediated Suppression of Histone Deacetylase 2. J. Allergy Clin. Immunol. 2017, 139, 519-532. [CrossRef]

71. Spahn, J.D.; Szefler, S.J.; Surs, W.; Doherty, D.E.; Nimmagadda, S.R.; Leung, D.Y. A Novel Action of IL-13: Induction of Diminished Monocyte Glucocorticoid Receptor-Binding Affinity. J. Immunol. 1996, 157, 2654-2659.

72. Pazdrak, K.; Moon, Y.; Straub, C.; Stafford, S.; Kurosky, A. Eosinophil Resistance to Glucocorticoid-Induced Apoptosis Is Mediated by the Transcription Factor NFIL3. Apoptosis 2016, 21, 421-431. [CrossRef] [PubMed]

73. McKinley, L.; Alcorn, J.F.; Peterson, A.; DuPont, R.B.; Kapadia, S.; Logar, A.; Henry, A.; Irvin, C.G.; Piganelli, J.D.; Ray, A.; et al. TH17 Cells Mediate Steroid-Resistant Airway Inflammation and Airway Hyperresponsiveness in Mice. J. Immunol. 2008, 181, 4089-4097. [CrossRef] [PubMed]

74. Chesné, J.; Braza, F.; Mahay, G.; Brouard, S.; Aronica, M.; Magnan, A. IL-17 in Severe Asthma. Where Do We Stand? Am. J. Respir Crit. Care Med. 2014, 190, 1094-1101. [CrossRef] 
75. Morishima, Y.; Ano, S.; Ishii, Y.; Ohtsuka, S.; Matsuyama, M.; Kawaguchi, M.; Hizawa, N. Th17-Associated Cytokines as a Therapeutic Target for Steroid-Insensitive Asthma. Clin. Dev. Immunol. 2013, 2013, 609395. [CrossRef] [PubMed]

76. Vazquez-Tello, A.; Semlali, A.; Chakir, J.; Martin, J.G.; Leung, D.Y.; Eidelman, D.H.; Hamid, Q. Induction of Glucocorticoid Receptor- $\beta$ Expression in Epithelial Cells of Asthmatic Airways by T-Helper Type 17 Cytokines. Clin. Exp. Allergy 2010, 40, 1312-1322. [CrossRef]

77. Kim, H.Y.; Lee, H.J.; Chang, Y.-J.; Pichavant, M.; Shore, S.A.; Fitzgerald, K.A.; Iwakura, Y.; Israel, E.; Bolger, K.; Faul, J.; et al. Interleukin-17-Producing Innate Lymphoid Cells and the NLRP3 Inflammasome Facilitate Obesity-Associated Airway Hyperreactivity. Nat. Med. 2014, 20, 54-61. [CrossRef]

78. Brandt, E.B.; Khurana Hershey, G.K. A Combination of Dexamethasone and Anti-IL-17A Treatment Can Alleviate Diesel Exhaust Particle-Induced Steroid Insensitive Asthma. J. Allergy Clin. Immunol. 2016, 138, 924-928.e2. [CrossRef]

79. Zhao, S.; Jiang, Y.; Yang, X.; Guo, D.; Wang, Y.; Wang, J.; Wang, R.; Wang, C. Lipopolysaccharides Promote a Shift from Th2Derived Airway Eosinophilic Inflammation to Th17-Derived Neutrophilic Inflammation in an Ovalbumin-Sensitized Murine Asthma Model. J. Asthma 2017, 54, 447-455. [CrossRef]

80. Hawrylowicz, C.; Richards, D.; Loke, T.-K.; Corrigan, C.; Lee, T. A Defect in Corticosteroid-Induced IL-10 Production in T Lymphocytes from Corticosteroid-Resistant Asthmatic Patients. J. Allergy Clin. Immunol. 2002, 109, 369. [CrossRef]

81. Hirahara, K.; Mato, N.; Hagiwara, K.; Nakayama, T. The Pathogenicity of IL-33 on Steroid-Resistant Eosinophilic Inflammation via the Activation of Memory-Type ST2+CD4+ T Cells. J. Leukoc. Biol. 2018, 104, 895-901. [CrossRef]

82. Bray, P.J.; Cotton, R.G.H. Variations of the Human Glucocorticoid Receptor Gene (NR3C1): Pathological and in Vitro Mutations and Polymorphisms. Hum. Mutat. 2003, 21, 557-568. [CrossRef]

83. Cruz-Topete, D.; Cidlowski, J.A. One Hormone, Two Actions: Anti- and Pro-Inflammatory Effects of Glucocorticoids. Neuroimmunomodulation 2015, 22, 20-32. [CrossRef] [PubMed]

84. Herath, K.H.I.N.M.; Kim, H.J.; Jang, J.-H.; Kim, H.-S.; Kim, H.J.; Jeon, Y.-J.; Jee, Y. Mojabanchromanol Isolated from Sargassum horneri Attenuates Particulate Matter Induced Inflammatory Responses via Suppressing TLR2/4/7-MAPK Signaling in MLE-12 Cells. Mar. Drugs 2020, 18, 355. [CrossRef] [PubMed]

85. Sanjeewa, K.K.A.; Jayawardena, T.U.; Lee, H.G.; Herath, K.H.I.N.M.; Jee, Y.; Jeon, Y.-J. The Protective Effect of Sargassum horneri against Particulate Matter-Induced Inflammation in Lung Tissues of an in Vivo Mouse Asthma Model. Food Funct. 2019, 10, 7995-8004. [CrossRef] [PubMed]

86. Herath, K.H.I.N.M.; Kim, H.J.; Mihindukulasooriya, S.P.; Kim, A.; Kim, H.J.; Jeon, Y.-J.; Jee, Y. Sargassum horneri Extract Containing Mojabanchromanol Attenuates the Particulate Matter Exacerbated Allergic Asthma through Reduction of Th2 and Th17 Response in Mice. Environ. Pollut. 2020, 265, 114094. [CrossRef]

87. Huang, J.; Su, M.; Lee, B.-K.; Kim, M.-J.; Jung, J.H.; Im, D.-S. Suppressive Effect of 4-Hydroxy-2-(4-Hydroxyphenethyl) Isoindoline1,3-Dione on Ovalbumin-Induced Allergic Asthma. Biomol. Ther. 2018, 26, 539-545. [CrossRef]

88. Lee, D.-I.; Kang, S.A.; Md, A.; Jeong, U.-C.; Jin, F.; Kang, S.-J.; Lee, J.-Y.; Yu, H.S. Sea Cucumber Lipid-Soluble Extra Fraction Prevents Ovalbumin-Induced Allergic Airway Inflammation. J. Med. Food 2018, 21, 21-29. [CrossRef] [PubMed]

89. Jayawardena, T.U.; Sanjeewa, K.K.A.; Lee, H.-G.; Nagahawatta, D.P.; Yang, H.-W.; Kang, M.-C.; Jeon, Y.-J. Particulate MatterInduced Inflammation/Oxidative Stress in Macrophages: Fucosterol from Padina boryana as a Potent Protector, Activated via NF-KB/MAPK Pathways and Nrf2/HO-1 Involvement. Mar. Drugs 2020, 18, 628. [CrossRef]

90. Han, E.-J.; Jayawardena, T.U.; Jang, J.-H.; Fernando, I.P.S.; Jee, Y.; Jeon, Y.-J.; Lee, D.-S.; Lee, J.-M.; Yim, M.-J.; Wang, L.; et al. Sargachromenol Purified from Sargassum horneri Inhibits Inflammatory Responses via Activation of Nrf2/HO-1 Signaling in LPS-Stimulated Macrophages. Mar. Drugs 2021, 19, 497. [CrossRef]

91. Chen, X.; Ni, L.; Fu, X.; Wang, L.; Duan, D.; Huang, L.; Xu, J.; Gao, X. Molecular Mechanism of Anti-Inflammatory Activities of a Novel Sulfated Galactofucan from Saccharina japonica. Mar. Drugs 2021, 19, 430. [CrossRef]

92. Chakraborty, K.; Paulraj, R. Sesquiterpenoids with Free-Radical-Scavenging Properties from Marine Macroalga Ulva fasciata Delile. Food Chem. 2010, 122, 31-41. [CrossRef]

93. Shah, S.A.A.; Hassan, S.S.U.; Bungau, S.; Si, Y.; Xu, H.; Rahman, M.H.; Behl, T.; Gitea, D.; Pavel, F.-M.; Corb Aron, R.A.; et al. Chemically Diverse and Biologically Active Secondary Metabolites from Marine Phylum Chlorophyta. Mar. Drugs 2020, 18, 493. [CrossRef]

94. Manzoor, Z.; Koo, J.-E.; Ali, I.; Kim, J.-E.; Byeon, S.-H.; Yoo, E.-S.; Kang, H.-K.; Hyun, J.-W.; Lee, N.-H.; Koh, Y.-S. 4-Hydroxy2,3-Dimethyl-2-Nonen-4-Olide Has an Inhibitory Effect on Pro-Inflammatory Cytokine Production in CpG-Stimulated Bone Marrow-Derived Dendritic Cells. Mar. Drugs 2016, 14, 88. [CrossRef]

95. Lee, H.-J.; Dang, H.-T.; Kang, G.-J.; Yang, E.-J.; Park, S.-S.; Yoon, W.-J.; Jung, J.H.; Kang, H.-K.; Yoo, E.-S. Two Enone Fatty Acids Isolated from Gracilaria verrucosa Suppress the Production of Inflammatory Mediators by Down-Regulating NF-KappaB and STAT1 Activity in Lipopolysaccharide-Stimulated RAW 264.7 Cells. Arch. Pharm. Res. 2009, 32, 453-462. [CrossRef] [PubMed]

96. Jeong, S.; Ku, S.-K.; Min, G.; Choi, H.; Park, D.H.; Bae, J.-S. Suppressive Effects of Three Diketopiperazines from Marine-Derived Bacteria on Polyphosphate-Mediated Septic Responses. Chem. Biol. Interact. 2016, 257, 61-70. [CrossRef]

97. Fürstner, A. Chemistry and Biology of Roseophilin and the Prodigiosin Alkaloids: A Survey of the Last 2500 Years. Angew. Chem. Int. Ed. 2003, 42, 3582-3603. [CrossRef]

98. Kamata, K.; Okamoto, S.; Oka, S.; Kamata, H.; Yagisawa, H.; Hirata, H. Cycloprodigiosin Hydrocloride Suppresses Tumor Necrosis Factor (TNF) Alpha-Induced Transcriptional Activation by NF-KappaB. FEBS Lett. 2001, 507, 74-80. [CrossRef] 
99. Jüttner, F.; Todorova, A.K.; Walch, N.; von Philipsborn, W. Nostocyclamide M: A Cyanobacterial Cyclic Peptide with Allelopathic Activity from Nostoc 31. Phytochemistry 2001, 57, 613-619. [CrossRef]

100. Anjum, K.; Abbas, S.Q.; Akhter, N.; Shagufta, B.I.; Shah, S.A.A.; Hassan, S.S.U. Emerging Biopharmaceuticals from Bioactive Peptides Derived from Marine Organisms. Chem. Biol. Drug Des. 2017, 90, 12-30. [CrossRef] [PubMed]

101. Hassan, S.S.U.; Anjum, K.; Abbas, S.Q.; Akhter, N.; Shagufta, B.I.; Shah, S.A.A.; Tasneem, U. Emerging Biopharmaceuticals from Marine Actinobacteria. Environ. Toxicol. Pharmacol. 2017, 49, 34-47. [CrossRef] [PubMed]

102. Anjum, K.; Abbas, S.Q.; Shah, S.A.A.; Akhter, N.; Batool, S.; Hassan, S.S.U. Marine Sponges as a Drug Treasure. Biomol. Ther. 2016, 24, 347-362. [CrossRef]

103. Hassan, S.S.U.; Shaikh, A.L. Marine Actinobacteria as a Drug Treasure House. Biomed. Pharmacother. 2017, 87, 46-57. [CrossRef] [PubMed]

104. Kondratyuk, T.P.; Park, E.-J.; Yu, R.; Van Breemen, R.B.; Asolkar, R.N.; Murphy, B.T.; Fenical, W.; Pezzuto, J.M. Novel Marine Phenazines as Potential Cancer Chemopreventive and Anti-Inflammatory Agents. Mar. Drugs 2012, 10, 451-464. [CrossRef] [PubMed]

105. Lee, D.-S.; Yoon, C.-S.; Jung, Y.-T.; Yoon, J.-H.; Kim, Y.-C.; Oh, H. Marine-Derived Secondary Metabolite, Griseusrazin A, Suppresses Inflammation through Heme Oxygenase-1 Induction in Activated RAW264.7 Macrophages. J. Nat. Prod. 2016, 79, 1105-1111. [CrossRef]

106. Kwan, J.C.; Eksioglu, E.A.; Liu, C.; Paul, V.J.; Luesch, H. Grassystatins A-C from Marine Cyanobacteria, Potent Cathepsin E Inhibitors That Reduce Antigen Presentation. J. Med. Chem. 2009, 52, 5732-5747. [CrossRef]

107. Kozuma, S.; Hirota-Takahata, Y.; Fukuda, D.; Kuraya, N.; Nakajima, M.; Ando, O. Identification and Biological Activity of Ogipeptins, Novel LPS Inhibitors Produced by Marine Bacterium. J. Antibiot. 2017, 70, 79-83. [CrossRef] [PubMed]

108. Toledo, T.R.; Dejani, N.N.; Monnazzi, L.G.S.; Kossuga, M.H.; Berlinck, R.G.S.; Sette, L.D.; Medeiros, A.I. Potent AntiInflammatory Activity of Pyrenocine A Isolated from the Marine-Derived Fungus Penicillium paxilli Ma(G)K. Mediat. Inflamm. 2014, 2014, e767061. [CrossRef] [PubMed]

109. Lu, X.; He, J.; Wu, Y.; Du, N.; Li, X.; Ju, J.; Hu, Z.; Umezawa, K.; Wang, L. Isolation and Characterization of New Anti-Inflammatory and Antioxidant Components from Deep Marine-Derived Fungus Myrothecium Sp. Bzo-L062. Mar. Drugs 2020, 18, 597. [CrossRef] [PubMed]

110. Chen, S.; Wang, J.; Lin, X.; Zhao, B.; Wei, X.; Li, G.; Kaliaperumal, K.; Liao, S.; Yang, B.; Zhou, X.; et al. Chrysamides A-C, Three Dimeric Nitrophenyl Trans-Epoxyamides Produced by the Deep-Sea-Derived Fungus Penicillium chrysogenum SCSIO41001. Org. Lett. 2016, 18, 3650-3653. [CrossRef] [PubMed]

111. Yang, X.; Du, L.; Tang, X.; Jung, S.-Y.; Zheng, B.; Soh, B.Y.; Kim, S.-Y.; Gu, Q.; Park, H. Brevicompanine E Reduces Lipopolysaccharide-Induced Production of Proinflammatory Cytokines and Enzymes in Microglia by Inhibiting Activation of Activator Protein-1 and Nuclear Factor-KB. J. Neuroimmunol. 2009, 216, 32-38. [CrossRef]

112. de Almeida Leone, P.; Redburn, J.; Hooper, J.N.; Quinn, R.J. Polyoxygenated Dysidea Sterols That Inhibit the Binding of [I125] IL-8 to the Human Recombinant IL-8 Receptor Type A. J. Nat. Prod. 2000, 63, 694-697. [CrossRef] [PubMed]

113. Busserolles, J.; Payá, M.; D’Auria, M.V.; Gomez-Paloma, L.; Alcaraz, M.J. Protection against 2,4,6-Trinitrobenzenesulphonic AcidInduced Colonic Inflammation in Mice by the Marine Products Bolinaquinone and Petrosaspongiolide M. Biochem. Pharmacol. 2005, 69, 1433-1440. [CrossRef] [PubMed]

114. Jan, J.-S.; Yang, C.-H.; Wang, M.-H.; Lin, F.-L.; Yen, J.-L.; Hsieh, I.; Khotimchenko, M.; Lee, T.-H.; Hsiao, G. Hirsutanol A Attenuates Lipopolysaccharide-Mediated Matrix Metalloproteinase 9 Expression and Cytokines Production and Improves Endotoxemia-Induced Acute Sickness Behavior and Acute Lung Injury. Mar. Drugs 2019, 17, 360. [CrossRef] [PubMed]

115. Kwon, I.-S.; Kwak, J.H.; Pyo, S.; Lee, H.-W.; Kim, A.; Schmitz, F.J. Oscarellin, an Anthranilic Acid Derivative from a Philippine Sponge, Oscarella stillans, as an Inhibitor of Inflammatory Cytokines in Macrophages. J. Nat. Prod. 2017, 80, 149-155. [CrossRef]

116. Lin, C.-Y.; Lu, M.-C.; Su, J.-H.; Chu, C.-L.; Shiuan, D.; Weng, C.-F.; Sung, P.-J.; Huang, K.-J. Immunomodulatory Effect of Marine Cembrane-Type Diterpenoids on Dendritic Cells. Mar. Drugs 2013, 11, 1336-1350. [CrossRef]

117. Liu, C.-Y.; Hwang, T.-L.; Lin, M.-R.; Chen, Y.-H.; Chang, Y.-C.; Fang, L.-S.; Wang, W.-H.; Wu, Y.-C.; Sung, P.-J. Carijoside A, a Bioactive Sterol Glycoside from an Octocoral Carijoa Sp. (Clavulariidae). Mar. Drugs 2010, 8, 2014-2020. [CrossRef]

118. Tseng, W.-R.; Huang, C.-Y.; Tsai, Y.-Y.; Lin, Y.-S.; Hwang, T.-L.; Su, J.-H.; Sung, P.-J.; Dai, C.-F.; Sheu, J.-H. New Cytotoxic and Anti-Inflammatory Steroids from the Soft Coral Klyxum flaccidum. Bioorg. Med. Chem. Lett. 2016, 26, 3253-3257. [CrossRef]

119. Tsai, Y.-Y.; Huang, C.-Y.; Tseng, W.-R.; Chiang, P.-L.; Hwang, T.-L.; Su, J.-H.; Sung, P.-J.; Dai, C.-F.; Sheu, J.-H. Klyflaccisteroids K-M, Bioactive Steroidal Derivatives from a Soft Coral Klyxum flaccidum. Bioorg. Med. Chem. Lett. 2017, 27, 1220-1224. [CrossRef]

120. Appleton, D.R.; Chuen, C.S.; Berridge, M.V.; Webb, V.L.; Copp, B.R. Rossinones A and B, Biologically Active Meroterpenoids from the Antarctic Ascidian, Aplidium Species. J. Org. Chem. 2009, 74, 9195-9198. [CrossRef]

121. Ahmad, T.B.; Rudd, D.; Benkendorff, K.; Mahdi, L.K.; Pratt, K.-A.; Dooley, L.; Wei, C.; Kotiw, M. Brominated Indoles from a Marine Mollusc Inhibit Inflammation in a Murine Model of Acute Lung Injury. PLoS ONE 2017, 12, e0186904. [CrossRef]

122. Kijjoa, A.; Sawangwong, P. Drugs and Cosmetics from the Sea. Mar. Drugs 2004, 2, 73-82. [CrossRef]

123. Ankisetty, S.; Khan, S.I.; Avula, B.; Gochfeld, D.; Khan, I.A.; Slattery, M. Chlorinated Didemnins from the Tunicate Trididemnum solidum. Mar. Drugs 2013, 11, 4478-4486. [CrossRef]

124. Strangman, W.K.; Kwon, H.C.; Broide, D.; Jensen, P.R.; Fenical, W. Potent Inhibitors of Pro-Inflammatory Cytokine Production Produced by a Marine-Derived Bacterium. J. Med. Chem. 2009, 52, 2317-2327. [CrossRef] 
125. Huang, C.-Y.; Tseng, Y.-J.; Chokkalingam, U.; Hwang, T.-L.; Hsu, C.-H.; Dai, C.-F.; Sung, P.-J.; Sheu, J.-H. Bioactive IsoprenoidDerived Natural Products from a Dongsha Atoll Soft Coral Sinularia erecta. J. Nat. Prod. 2016, 79, 1339-1346. [CrossRef] [PubMed]

126. Herath, K.H.I.N.M.; Kim, H.J.; Lee, J.H.; Je, J.G.; Yu, H.-S.; Jeon, Y.-J.; Kim, H.J.; Jee, Y. Sargassum horneri (Turner) C. Agardh Containing Polyphenols Attenuates Particulate Matter-Induced Inflammatory Response by Blocking TLR-Mediated MYD88Dependent MAPK Signaling Pathway in MLE-12 Cells. J. Ethnopharmacol. 2021, 265, 113340. [CrossRef]

127. Jayawardena, T.U.; Asanka Sanjeewa, K.K.; Shanura Fernando, I.P.; Ryu, B.M.; Kang, M.-C.; Jee, Y.; Lee, W.W.; Jeon, Y.-J. Sargassum horneri (Turner) C. Agardh Ethanol Extract Inhibits the Fine Dust Inflammation Response via Activating Nrf2/HO-1 Signaling in RAW 264.7 Cells. BMC Complement. Altern. Med. 2018, 18, 249. [CrossRef]

128. Sanjeewa, K.K.A.; Jayawardena, T.U.; Kim, S.-Y.; Lee, H.G.; Je, J.-G.; Jee, Y.; Jeon, Y.-J. Sargassum horneri (Turner) Inhibit Urban Particulate Matter-Induced Inflammation in MH-S Lung Macrophages via Blocking TLRs Mediated NF-KB and MAPK Activation. J. Ethnopharmacol. 2020, 249, 112363. [CrossRef] [PubMed]

129. Kim, M.E.; Jung, Y.C.; Jung, I.; Lee, H.-W.; Youn, H.-Y.; Lee, J.S. Anti-Inflammatory Effects of Ethanolic Extract from Sargassum horneri (Turner) C. Agardh on Lipopolysaccharide-Stimulated Macrophage Activation via NF-KB Pathway Regulation. Immunol. Investig. 2015, 44, 137-146. [CrossRef] [PubMed]

130. Na, H.-J.; Moon, P.-D.; Ko, S.-G.; Lee, H.-J.; Jung, H.-A.; Hong, S.-H.; Seo, Y.; Oh, J.-M.; Lee, B.-H.; Choi, B.-W.; et al. Sargassum hemiphyllum Inhibits Atopic Allergic Reaction via the Regulation of Inflammatory Mediators. J. Pharmacol. Sci. 2005, 97, 219-226. [CrossRef] [PubMed]

131. Wang, S.; Ni, L.; Fu, X.; Duan, D.; Xu, J.; Gao, X. A Sulfated Polysaccharide from Saccharina japonica Suppresses LPS-Induced Inflammation Both in a Macrophage Cell Model via Blocking MAPK/NF-KB Signal Pathways In Vitro and a Zebrafish Model of Embryos and Larvae In Vivo. Mar. Drugs 2020, 18, 593. [CrossRef]

132. Wang, L.; Yang, H.-W.; Ahn, G.; Fu, X.; Xu, J.; Gao, X.; Jeon, Y.-J. In Vitro and In Vivo Anti-Inflammatory Effects of Sulfated Polysaccharides Isolated from the Edible Brown Seaweed, Sargassum fulvellum. Mar. Drugs 2021, 19, 277. [CrossRef] [PubMed]

133. Ma, X.; Xie, B.; Du, J.; Zhang, A.; Hao, J.; Wang, S.; Wang, J.; Cao, J. The Anti-Inflammatory Effect and Structure of EPCP1-2 from Crypthecodinium cohnii via Modulation of TLR4-NF-KB Pathways in LPS-Induced RAW 264.7 Cells. Mar. Drugs 2017, 15, 376. [CrossRef] [PubMed]

134. Macagno, A.; Molteni, M.; Rinaldi, A.; Bertoni, F.; Lanzavecchia, A.; Rossetti, C.; Sallusto, F. A Cyanobacterial LPS Antagonist Prevents Endotoxin Shock and Blocks Sustained TLR4 Stimulation Required for Cytokine Expression. J. Exp. Med. 2006, 203, 1481-1492. [CrossRef] [PubMed]

135. Thorgersen, E.B.; Macagno, A.; Rossetti, C.; Mollnes, T.E. Cyanobacterial LPS Antagonist (CyP)-a Novel and Efficient Inhibitor of Escherichia Coli LPS-Induced Cytokine Response in the Pig. Mol. Immunol. 2008, 45, 3553-3557. [CrossRef] [PubMed]

136. Molteni, M.; Bosi, A.; Rossetti, C. The Effect of Cyanobacterial LPS Antagonist (CyP) on Cytokines and Micro-RNA Expression Induced by Porphyromonas gingivalis LPS. Toxins 2018, 10, 290. [CrossRef]

137. Yang, H.-N.; Lee, E.-H.; Kim, H.-M. Spirulina Platensis Inhibits Anaphylactic Reaction. Life Sci. 1997, 61, 1237-1244. [CrossRef]

138. Appel, K.; Munoz, E.; Navarrete, C.; Cruz-Teno, C.; Biller, A.; Thiemann, E. Immunomodulatory and Inhibitory Effect of Immulina ${ }^{\circledR}$, and Immunloges ${ }^{\circledR}$ in the Ig-E Mediated Activation of RBL-2H3 Cells. A New Role in Allergic Inflammatory Responses. Plants 2018, 7, 13. [CrossRef]

139. Rod-in, W.; Monmai, C.; Lee, S.; Jung, S.-K.; You, S.; Park, W.J. Anti-Inflammatory Effects of Lipids Extracted from Arctoscopus japonicus Eggs on LPS-Stimulated RAW264.7 Cells. Mar. Drugs 2019, 17, 580. [CrossRef]

140. Li, Y.; Lee, S.-H.; Le, Q.-T.; Kim, M.-M.; Kim, S.-K. Anti-Allergic Effects of Phlorotannins on Histamine Release via Binding Inhibition between IgE and FceRI. J. Agric. Food Chem. 2008, 56, 12073-12080. [CrossRef]

141. Niu, S.; Liu, Q.; Xia, J.-M.; Xie, C.-L.; Luo, Z.-H.; Shao, Z.; Liu, G.; Yang, X.-W. Polyketides from the Deep-Sea-Derived Fungus Graphostroma Sp. MCCC 3A00421 Showed Potent Antifood Allergic Activities. J. Agric. Food Chem. 2018, 66, 1369-1376. [CrossRef]

142. Gao, Y.-Y.; Liu, Q.-M.; Liu, B.; Xie, C.-L.; Cao, M.-J.; Yang, X.-W.; Liu, G.-M. Inhibitory Activities of Compounds from the Marine Actinomycete williamsia Sp. MCCC 1A11233 Variant on IgE-Mediated Mast Cells and Passive Cutaneous Anaphylaxis. J. Agric. Food Chem. 2017, 65, 10749-10756. [CrossRef]

143. Lee, D.-I.; Park, M.-K.; Kang, S.A.; Choi, J.-H.; Kang, S.-J.; Lee, J.-Y.; Yu, H.S. Preventive Intra Oral Treatment of Sea Cucumber Ameliorate OVA-Induced Allergic Airway Inflammation. Am. J. Chin. Med. 2016, 44, 1663-1674. [CrossRef]

144. Onodera, K.; Konishi, Y.; Taguchi, T.; Kiyoto, S.; Tominaga, A. Peridinin from the Marine Symbiotic Dinoflagellate, Symbiodinium Sp., Regulates Eosinophilia in Mice. Mar. Drugs 2014, 12, 1773-1787. [CrossRef] 